\title{
Remittances and protests against crime in Mexico
}

Article

Accepted Version

Ley, S., Ibarra-Olivo, J. E. ORCID: https://orcid.org/0000-00023873-2886 and Meseguer, C. (2021) Remittances and protests against crime in Mexico. International Migration Review. ISSN 1747-7379 doi: https://doi.org/10.1177/01979183211011428 Available at https://centaur.reading.ac.uk/98480/

It is advisable to refer to the publisher's version if you intend to cite from the work. See Guidance on citing.

To link to this article DOI: http://dx.doi.org/10.1177/01979183211011428

Publisher: SAGE Publications

All outputs in CentAUR are protected by Intellectual Property Rights law, including copyright law. Copyright and IPR is retained by the creators or other copyright holders. Terms and conditions for use of this material are defined in the End User Agreement.

\section{www.reading.ac.uk/centaur}

\section{CentAUR}

Central Archive at the University of Reading

Reading's research outputs online 


\title{
Remittances and Protests against Crime in Mexico
}

\author{
Sandra Ley (Sandra.ley@ cide.edu) \\ Center for Research and Teaching in Economics \\ Carretera Mexico-Toluca 3655, Lomas de Sta Fe, Ciudad de Mexico \\ Mexico \\ J. Eduardo Ibarra Olivo (j.ibarra-olivo@ Ise.ac.uk) \\ Department of Geography, London School of Economics and Political Science \\ Houghton Street, London WC2A 2AE \\ United Kingdom \\ Covadonga Meseguer (covadonga.meseguer@gmail.com)*** \\ ICADE-ICAI, Universidad Pontificia Comillas \\ Alberto Aguilera 23, 28015 Madrid \\ Spain \\ ****Corresponding Author
}

\section{Declaration of Interest: None}

We thank the editor and three reviewers for their thorough reading of our manuscript. We also thank participants at the $16^{\text {th }}$ IMISCOE Annual Meeting for their useful comments. Benjamin Nyblade and Brian Phillips shared some of the data we employed in the article. 


\begin{abstract}
The resource mobilization theory has long emphasized the role of resources in facilitating collective mobilization. In turn, recent research on crime and insecurity in Mexico has drawn attention to the role of local networks of solidarity in facilitating mobilization against crime. We rely on these two literatures to propose that remittances - that is, the resources that emigrants send to their relatives left behind - deserve attention as international determinants of this type of non-violent anti-crime mobilization. Further, relying on recent research on remittances' impact on political behavior, we hypothesize that the relationship between remittances and contentious action is non-linear, exhibiting a positive effect at low to moderate levels of inflows and declining at higher levels of remittances. We contend that at low to moderate levels, international remittances provide the necessary resources for collective activation. At greater levels of inflows, however, lessened economic and security grievances imply a decline in the probability of protesting. Overall, we show that emigrant remittances matter for organizing protests against criminality at the subnational level but that they produce both an engagement and disengagement effect, depending on the size of the inflows.
\end{abstract}

\title{
Introduction
}

In this article, we explore whether migrant remittances - the money emigrants send to their relatives and friends - help families left behind organize against crime in Mexico (Pansters 2018; Guerrero 2018; Trejo and Ley 2019). ${ }^{1}$ In particular, we study whether remittances help recipients invest time and resources in peaceful protest against the persistent increase in insecurity, as well as against the Mexican state's inefficacy to protect its citizens amid this surge in violence (Cárdenas 2016; Martínez 2017).

The resource mobilization theory is one approach that research on the determinants of protests has identified as a facilitator of mobilization (Gurr 1970; Brady et al. 1995; White et al. 2015). Without resources, this theory proposes, aggrieved audiences may be left without options for manifesting their discontent (McCarthy and Zald 2002). Resource availability, on

\footnotetext{
${ }^{1}$ In this article, we study the impact of individual remittances, rather than collective remittances, on protest. Collective remittances are raised by migrant organizations in destination countries and frequently finance public investments in migrants' origin communities (e.g., Burgess (2005) and Duquette-Rury (2014)). See also Pérez-Armendáriz and Duquette-Rury (2019) for a study of collective remittances and vigilantism in Mexico.
} 
the other hand, can facilitate collective organization by freeing time to devote to civilian protests, enhancing the sense of citizens' perceived efficiency and facilitating coordination and organization efforts (Gurr 1970; Brady et al. 1995; White et al. 2015). In the particular case of protests against crime and insecurity in violent democracies, recent research has shown that besides financial commitment, the existence of local networks of solidarity in the form of a vibrant civil society also facilitates protests (Ley 2014; Dorff 2017). As we explain below, these networks help give visibility to victims' grief and demands, creating solidarity between victims and non-victims (Ley 2014; Rojo-Mendoza 2014; Durán-Martínez 2016; Dorff 2017). While the literature on mobilization against crime has acknowledged the crucial role of local networks of solidarity in animating victims and non-victims to protest (Ley 2014; RojoMendoza 2014; Durán-Martínez 2016; Dorff 2017), it has overlooked the possibility that international migrant networks may also play a role in those mobilizations.

In this article, we argue that migrants' remittances should be considered determinants of protests against crime. Emigrants keep a host of relationships with their relatives left behind and frequently send financial support (World Bank 2006). We argue that these flows provide extra resources for the collective mobilization of those left behind. In hypothesizing about the relationship between remittances and protest, we rely on the thriving literature on the consequences of remittances for political behavior (Goodman and Hiskey 2008; Bravo 2009; Córdova and Hiskey 2019; Germano 2018). Often, this literature reports contradictory effects of remittances on political participation, with remittances being associated with both political engagement and disengagement (Goodman and Hiskey 2008; Bravo 2009; Pfutze 2014; Córdova and Hiskey 2015; Escribà-Folch et al. 2018; Duquette-Rury and Chen 2018). Some authors report a decrease in electoral participation among remittance recipients (Bravo 2009; Germano 2013, 2018; Pfutze 2014; Duquette-Rury and Chen 2018) while others show that remittances stimulate non-electoral political activism, such as belonging to civil organizations 
or engaging in political discussions (Goodman and Hiskey 2008; Córdova and Hiskey 2019). Among the panoply of non-electoral political activities that remittances may affect, protest has barely been researched (Pérez-Armendáriz and Crow 2010; Dionne et al 2014; Escribà-Folch et al. 2018; Germano 2018).

We present a theory to fill this gap. In the particular case of protests against crime, we argue that remittances can cause both an increase and a decrease in the likelihood of protesting and that these effects are evident at different levels of remittance penetration at the local level. In other words, we argue that remittances have a non-linear effect on protests, by which higher volumes of remittances, while still increasing the probability of protesting, do so at a declining rate. We attribute this slowdown to lessened economic and security grievances, as well as to recipients' greater economic autonomy in settings where remittances flow in abundance (Adams and Page 2005; Doyle 2015; Escribà-Folch et al. 2018; López and Doyle 2019).

In developing our theory, we build bridges between the literature on local mobilization against crime and on transnational migrant involvement, with a focus on the vibrant research agenda examining remittances' political impacts in origin countries (Goodman and Hiskey 2008; Bravo 2009; Pfutze 2014; Córdova and Hiskey 2019; Escribà-Folch et al. 2018; Duquette-Rury and Chen 2018; Germano 2018). In so doing, our article contributes to a better understanding of the multifaceted consequences that remittances have in out-migration settings.

The article proceeds as follows. First, we give some background on the evolution of crime in Mexico, an example of a "violent democracy" "in which competitive elections, civil freedoms, and inclusive participation have taken root yet and the state does not control substate violence" (Pérez-Armendáriz 2019, 2). We also discuss the correlates of this violence. Second, we discuss the literature on remittances and the mechanisms by which remittances may shape protest against crime. Third, we present our data and empirical strategy. Our 
analysis uses an original dataset coding over one-thousand instances of protest against crime in Mexico in the period, 2006-2012 (Ley 2014). We account for the endogenous nature of remittances and use an instrumental variable approach to test a non-linear relationship between remittances and protest against crime. We conclude with some reflections on the relevance of our findings and with suggestions for the research agenda ahead.

\section{Crime and Protest Against Crime in Mexico}

Rising insecurity in Mexico over the past decade has drawn international attention, but violence has been persistently present across the country throughout the twentieth and twentyfirst centuries (Pansters 2018). This violence has been sustained by deep connections between the Mexican state and a diverse set of violent actors that proliferated over the course of decades - from caciques (local political bosses) to drug lords and vigilante groups (Pansters 2018). As noted by Pérez-Armendáriz (2019), Mexico stands as a "quintessential violent democracy," having ongoing functional electoral institutions and corresponding civic engagement yet also being a state historically unable to hold the monopoly on violence.

It is against this backdrop that one must understand the "War on Drugs" initiated by Mexican president Felipe Calderón in 2006. A militarized strategy to fight organized crime amid the continued overlap between the Mexican state and drug trafficking organizations resulted in the multiplication of armed actors, and competition among them exacerbated violence and insecurity across the country (Guerrero 2018). Mexico is today the eighth most violent country in Latin America (WHO 2015). Between 2006 and 2016, more than 100,000 people died as a result of armed confrontations among Mexican cartels, their private armies, and the Mexican military and police forces (Justice in Mexico Organized Crime and Violence Reports). ${ }^{2}$ In addition, more than 25,000 people have disappeared, not a few of them at the

\footnotetext{
${ }^{2}$ https://justiceinmexico.org/publications/reports/ (Accessed 24 March, 2021).
} 
hands of Mexican government forces (Human Rights Watch, 2013), while more than 300 local authorities, political candidates, and party activists have been direct victims of organized crime (Trejo and Ley 2019). During the Calderón and subsequent administrations, organized crime groups multiplied in Mexico, no longer consisting of a handful of cartels, but dozens of them, along with hundreds of street gangs (Guerrero 2018).

The deep connections between the Mexican state and organized crime, and the subsequent failure of security and judicial institutions to contain and punish crime (Cárdenas 2016), have discouraged Mexican citizens from reporting criminal activity, despite growing insecurity and their increasing personal encounters with violence (Smulovitz and Peruzzotti 2009). When the traditional institutional channels for reporting crime and achieving justice are weak, civil society can take action to hold governments accountable, expose governmental wrongdoing, or activate horizontal checks (Smulovitz and Peruzzotti 2009). Such has been the case in Mexico. In the face of rising violence, Mexican citizens have made an effort to keep government authorities accountable for the issue of insecurity through diverse non-electoral mechanisms, among which protest has been a recurring tool (Knox 2018). According to Ley (2014), between 2006 and 2012 - the peak period of criminal violence during the Calderón administration - more than a thousand protest events against crime and insecurity were voluntarily organized by civilians across Mexico. Through these actions, victims and their relatives have told of the violence they have experienced, revealed information on the collusion between public authorities and criminal groups, and denounced the many obstacles they face when attempting to report and prosecute their cases through judicial institutions.

As protest scholars have argued (McCarthy and Zald 2002; Brancati 2014), grievances are not enough for mobilization to take place. Specifically, as the resource mobilization theory has put forward, participation in social movements involves spending time, energy, and money 
(Brady et al. 1995; White et al. 2015). Consequently, those groups with "few resources are less able to act on grievances or perceived injustices" (McCarthy and Zald 2002, 535). The availability of community resources - broadly defined as actual wealth coming from contributions, transfer payments, and per capita income, together with organizational skills and local associations and groups - has been found to be crucial for the likelihood that social movement organizations can mobilize (McCarthy et al. 1988; Khawaja 1994).

We argue that protests occurring amid criminal violence and in reaction to crime also require a diverse set of resources: in addition to monetary funds that enable the mobilization of relatives searching for their missing loved ones (Ahmed 2017), local networks of support have been crucial to the development of organized responses to crime (Ley 2014; Durán-Martínez 2016; Dorff 2017). The findings of these works are consistent with those that have examined collective action under conditions of high risk and that also emphasize the importance of networks of solidarity for protesting against crime (McAdam 1986; Loveman 1998).

According to Ley (2014), protest against crime in Mexico has been enabled by mobilizing formal (legally constituted) associations and informal arrangements of victims and non-victims that contribute in instrumental and non-instrumental ways to take action in response to crime. ${ }^{3}$ From a non-instrumental viewpoint, embeddedness in networks generates a sense of solidarity, as participants share their experiences, become aware of their commonalities, overcome fear, and foster a sense of collective indignation, as proposed by Loveman (1998) and Wood (2003). From an instrumental perspective - as widely noted by classic works on social networks and protests (DellaPorta 1988; Gould 1993; Klandermans 1997; McAdam 1986) - socialization within networks opens opportunities to participate, in addition to reducing associated risks (Keck and Sikkink 1998). Both instrumental and non-

\footnotetext{
${ }^{3}$ The distinction between formal and informal social networks is well established in the literature on social capital. See, for instance, Putnam (2000).
} 
instrumental functions within social networks are particularly relevant for protest against crime. As noted by Ley (2014), participants face relatively higher risks in such mobilizations, as they are more likely to be threatened or co-opted by both criminals and colluded government authorities or security forces that sustain protection networks and that have been historically intertwined with organized crime in Mexico (Pansters 2018). This double threat is unique to protest against crime because when participants in these mobilizations raise their voices to denounce violence, they are likely to attract the unwanted attention of criminals, as well as to put protection networks at risk and reveal the identity of colluding state officials (Ley 2014, 42).

Durán-Martínez (2016) further examines the conditions under which victims and nonvictims may come together to develop organized responses to crime. The author finds that when criminals claim responsibility for acts or when attacks by criminals are publicly exposed, this shared knowledge on the responsible actor behind the violence helps mobilize non-victims by making them more sympathetic to victims and creating a sense of victimization among wider segments of the population. Finally, Dorff (2017) has shown the relevance of kinship ties in transforming victimization into political activation.

In view of the relevance of grievances to protest, of resource availability to mobilization, and of civilian networks in fostering protests, it is surprising that the role of emigrant connections and the money flows linked to these connections have remained unexplored in efforts to understand protest against crime in Mexican states. In what follows, we propose a theory based on how remittances shape the perception of grievances, potentially provide resources to the aggrieved, and may facilitate collective action against crime.

\section{Remittances, Networks, and Grievances}


The role of relatives abroad in supporting protest against crime at home should be given systematic attention: anecdotal and systematic evidence reveals that different types of local mobilization against crime, notably vigilantism, have relied on the individual and collective resources that migrants send back to their families (Pérez-Armendáriz and Duquette-Rury 2019; Ley et al. 2019). Moreover, instances of collective mobilization have often been led by individuals with migrant backgrounds. ${ }^{4}$ Here, we study the role of remittances as one of the international factors that may have facilitated domestic protest against crime in Mexico.

Through which mechanisms, however, may remittances affect the likelihood of recipients and their communities engaging in protest? As explained in the previous section, grievances are a necessary pre-existing condition, but insufficient if resources are lacking. Further, the existence of networks of solidarity helps victims make those grievances visible, catalyzing collective action. We posit that remittances' impact on grievances and on the motivations to collectively express and denounce those grievances are multifaceted and vary with the largess of the inflows of remittances.

On one hand, according to the resource mobilization theory (Brady et al. 1995; White et al. 2015), remittances provide extra income for households left behind, increasing the resources available for gathering information, coordinating, and making more time available to be politically active. As Ley (2014) explains, over the 2006-2012 period, mobilizations against crime in Mexico were initially led by human rights organizations, along with other formal networks such as churches and professional associations of journalists, teachers, and healthcare workers. All of these groups constitute official civil society organizations. However, around half the collective action processes were organized by informal networks linked through

\footnotetext{
4 "Quiénes son los líderes de los autodefensas," Milenio 12 February, 2014 http://www.milenio.com/policia/quienes-son-los-lideres-de-las-autodefensas (accessed 23 March, 2021).
} 
personal ties, not through institutionalized organizations - mainly networks of new victims and their relatives, who had never been part of protests in the past. Two additional informal networks contributed to protests against crime: neighborhood groups and informal merchants, whose interpersonal ties helped them react to shared concerns about rising insecurity and organize accordingly (Ley 2014).

Research on the political consequences of remittances has shown that remittance recipients are more likely to participate in informal cooperative networks, as remittances allow them to enter into "mutual help" and inter-household "risk-sharing arrangements" (Gallego and Mendola 2013, 722; Mendola 2017). In comparison to non-recipients, remittance recipients exhibit pro-social behavior, such as volunteering work to the community, donating, or helping strangers (Fransen 2015; Gerber and Torosyan 2013; Nikolova et al. 2017). Through these activities, remittances strengthen norms of reciprocity and trust, with effects that transcend the recipient household and generate organizational spillover effects at the community level (Pérez-Armendáriz and Crow 2010, 125; Mendola 2017, 289; Fransen 2015, 1295; Gerber and Torosyan 2013, 1283). ${ }^{5}$ Thus, remittances' income effect can facilitate collective action and shape mobilization repertoires and technologies in remittance-receiving communities, from the types of protest activity a movement can organize and carry out to participants' level of engagement, possibly transforming them from simple sympathizers to avid adherents. The expectation under the resource mobilization mechanism is straightforward: the income effect of migrants' remittances should increase the likelihood of non-violent mobilization against crime in remittance-receiving communities.

On the other hand, grievances are regarded as a major cause of protests (Gurr 1970; Brancati 2014). Recent research shows that remittances shape economic and security

\footnotetext{
${ }^{5}$ Some authors have found that remittances also enable the formation of rebel groups (Miller and Ritter 2014).
} 
grievances. First, many scholars have found that the rise in income caused by remittances improves the living conditions of stayers, reduces poverty, and provides insurance against different types of risks (Chami et al. 2008; Adams and Page 2005; Yang and Choi 2007). Particularly in times of economic hardship, remittances reduce economic grievances. According to the predictions of political behavior models that emphasize how the economy shapes voting decisions - also known as "pocketbook" models of voting (Pop-Eleches and Pop-Eleches 2012) - remittance recipients may wrongly attribute the betterment of their economic situation to incumbents rather than to their relatives (Tertychnaya et al. 2018). This wrong attribution, in turn, may boost the approval of the government (Germano 2018; Tertychnaya et al. 2018). Also, remittances' positive economic effects transcend the receiving household and have multiplier effects that improve the state of the economy at the community level (Durand et al. 1996; Zárate-Hoyos 2005). Overall, remittances reduce economic grievances.

Interestingly, new research on Mexico surmises that besides impacting economic grievances, receiving remittances is positively associated with recipients' improved perceptions of their security situation in their neighborhoods or, in other words, with fewer security grievances. For instance, according to Doyle and López (2019), remittance recipients are also more likely to make investments to improve their safety, such as moving to safer neighborhoods or avoiding public transportation. For these reasons, remittance recipients evaluate their personal and family exposure to crime more positively than do those who do not receive remittances (Doyle and López 2019, 5). In other words, receiving remittances makes recipients feel safer in comparison to non-recipient peers. Fewer economic and security grievance leads to the expectation that remittances should be associated with less mobilization against crime. 
Further, and related to the above, the extra income of remittances and the subsequent reduction in poverty provide recipient households with access to goods often provided by states, making them less dependent on publicly provided services (Yang and Choi 2007; Adams and Page 2005; Adida and Girod 2011; Ambrosius 2019). The bulk of research on this substitution effect has focused on policies related to education and health, as well as housing, public infrastructure, water, and sanitation; but preliminary evidence suggests that remittances could allow recipients to have greater and better access to public and private security and to afford legal assistance (López and Doyle 2019). As Brito et al. (2014, 8) state, "the family abroad can send extra money to pay for private security." As a result of this substitution effect, if recipients can afford to become their own providers of security and, in general, feel safer than non-remittance recipients, remittance inflows could reduce recipients' incentives to organize collectively with others in reaction to crime. With rising remittances and fewer grievances, recipients may feel less motivation to join efforts with others to protest against crime and instead "bond" with their closest family network (Fransen 2015). In sum, then, remittances' substitution effect also anticipates less likelihood of engaging in protests against insecurity. High levels of remittance penetration would be associated with no effect or a decreasing impact of remittances on the likelihood of protesting.

Note that different mechanisms lead to different predictions regarding the relationship between remittance inflows and the likelihood of engaging in collective action against crime. Remittances provide the aggrieved with the resources to protest; but at the same time, remittances lower economic and security grievances and, consequently, the motives to protest. Rather than adjudicating between these two alternative observable implications, we postulate that these effects are prevalent at different degrees of local penetration of remittances. We contend that the resource mechanism prevails at a low to medium level of remittances, increasing the likelihood of protesting, but that the reduction in grievances and substitution 
effects are evident at high levels of remittances. We posit that because remittances are primarily spent on basic needs (World Bank 2006; Chami et al. 2008; Adams and Page 2005), it may take sizable transfers for recipients to perceive a clear reduction in economic hardship and observe multiplier effects at the local level and an even larger inflow to be able to afford private means of protection and have better access to justice. For poor households, however, the best hope of attracting public attention and securing their own protection may well be devoting resources and time to organizing with other victims and non-victims to voice their grievances (Ley 2014; Phillips 2017; Ley et al. 2019). In other words, the option of disengaging from networks of mutual help or experiencing a tangible reduction in economic and security threats may be visible only in settings of high remittance presence. At those levels, recipients may be less dependent on risk-sharing arrangements, as remittances may 'crowd out' "their incentives to participate in activities that cross[ed] social divides" (Fransen 2015, 1297). Therefore, our working hypothesis is:

There is a non-linear relationship between the inflow of remittances and the probability of engagement in protests against crime: Remittances increase the likelihood of protesting at low to moderate levels, but as grievances decrease and substitution effects kick in at high levels of remittance inflows, remittances decrease or have no effect on the likelihood of protesting.

\section{Data and Empirical Strategy}

\subsection{Data}

For reasons that we explain next, the state level of analysis is the most suitable, given our data on protest events. But also, as explained below, because remittances have social and economic effects that transcend the individual and the household, we contend that our theory has observable implications at this level of analysis. Our dataset includes a balanced panel of 
31 Mexican states (excluding Mexico City) and 22 time periods, from the first quarter of 2006 to the second quarter of 2011, yielding a total sample size of 682 state-quarter observations. Socioeconomic and political data were collected from various sources: National Statistical Institute (INEGI), Mexico's Interior Ministry, the Central Bank of Mexico (Banxico), the Mexican Protest against Crime Dataset (MPC, Ley 2014), and Nyblade and O’Mahony (2014). The summary statistics of all variables, as well as their periodicity, are reported in Table 1.

*** Table 1 about here $* * *$

\section{Protest against Crime}

The dependent variable, protest against crime, is a count variable recording the number of protests in state $i$ and quarter $t$. These original data were collected at the state level, taken from the Mexican Protest Against Crime (MPC) Dataset (Ley, 2014). This unique database provides detailed information on 1,014 protest events against crime and insecurity that occurred during the 2006-2012 period across 31 Mexican states. It focuses exclusively on non-violent mobilization events organized by citizens as a means of freely expressing their opposition to a particularly violent event or general insecurity and demanding specific changes to security policies. As such, the MPC Dataset excludes protest events organized by criminal organizations against a particular branch of government or security force and public protests by police forces demanding greater security for their working conditions. ${ }^{6}$ The acts of citizen protest in this dataset include marches, demonstrations, road blockages, community meetings with

\footnotetext{
${ }^{6}$ The MPC Dataset excludes protests that explicitly supported specific criminal organizations as part of their goals or such public expressions during the protest event, as in the case of demonstrations organized in 2010 and 2011 in Michoacán to show support for La Familia - a criminal organization that largely controlled the Mexican state of Michoacán between 2009 and 2011.
} 
authorities, labor strikes, collective public prayers, sit-ins, collective press conferences and press releases, hunger strikes, flyer distribution, signature collection, and the occupation of government buildings. The dataset includes collective acts of protest in which a minimum of five individuals participated. Additionally, it is important to note that marches and demonstrations make up 86 percent of the total number of recorded events.

The information included in the MPC Dataset is mainly derived from a systematic review of fifty local newspapers and one national newspaper listed in Online Appendix Table A1. ${ }^{7}$ When newspaper information was insufficient, activity reports from human rights NGOs were used. While the MPC Dataset cannot provide an official count of protests against crime occurring in Mexico during the Calderón administration, the use of multiple sources significantly reduces sources of geographical or temporal bias in the dataset. Finally, the MPC Dataset collected the municipality of occurrence, along with other protest characteristics. ${ }^{8}$ However, municipal disaggregation would naturally generate a major urban bias, as victims and their relatives tended to organize protests in capital cities to have more impact and generate

\footnotetext{
${ }^{7}$ The national daily newspaper was Reforma, which has extensive coverage of northern Mexico, one of the regions most affected by violence (Shirk and Wallman 2015) and has covered news on marches for peace since as early as 1999 . The sample of fifty local dailies includes two newspapers for twelve states, one newspaper in nine states, and three newspapers in five states. Ley (2014) did not have direct access to news sources in the states of Campeche, Chiapas, Nayarit, Oaxaca, or Quintana Roo, but this limitation was partially overcome through the use of multiple regional newspaper sources. For instance, Diario de Yucatán covers information for the entire Yucatán Peninsula, including the states of Campeche and Quintana Roo. El Mural, based in the state of Jalisco, has a wide coverage of Pacific coast states, including Nayarit. The inclusion of local newspapers from Organización Editorial Mexicana (OEM) and Milenio, which reprint news from neighboring states, also allowed the author to obtain information on protest events in Chiapas and Oaxaca.

${ }^{8}$ The MPC Dataset also gathered information on the type of protest, the organizers' identity, and specific claims made by participants.
} 
more pressure, ${ }^{9}$ and assign protest events incorrectly, since news reports generally do not provide detailed information on different participants' places of origin. Thus, it is impossible to correctly disaggregate data at the municipal level, making the state level the ideal setting for data collection.

Our objective in this analysis is to explain the variation in the mobilization of civil society against crime as a function of received remittances across Mexican states, using quarterly data. As shown in Figure 1, there is significant variation in the spatial distribution of protests across Mexico, reinforcing the importance of explaining such state-level variance. Two northern states, Chihuahua and Nuevo León, along with the southern state of Guerrero, saw the highest number of protests during the almost six-year study period. Baja California, Sinaloa, and Veracruz followed closely and experienced between 49 and 60 protests during the same period.

$* * *$ Figure 1 about here $* * *$

\section{Remittances}

Our main explanatory variable is remittances for each state-quarter in its logarithmic form, measured in constant 2003 Mexican pesos (Nyblade and O’Mahony 2014). Throughout the period, the average state level of remittances was 1.6 billion Mexican pesos. Though with some seasonal variation, the average quarterly change in national remittances was 0.44 percent (see Figure A1 in the Online Appendix). The spatial distribution of average remittances across states during our study period is shown in Figure 2. Southern and central Mexican states had the highest volume of remittances, as they are historically also the areas of higher emigration (Burgess 2005; Bada 2016)). Recall that our goal is to explore whether remittances' posited

\footnotetext{
${ }^{9}$ Municipal authorities have no jurisdiction over organized crime-related activity.
} 
contradictory effect on protests varies in a non-linear way with the size of remittance inflows. Thus, in our estimations, we include the quadratic term of remittances and investigate whether remittances increase the probability of engaging in protests against crime, but at a declining rate after a certain amount of remittance inflows.

*** Figure 2 about here $* * *$

\section{Controls}

As in previous work (Ley et al. 2019), the control variables are mostly collected from census data, especially Encuesta Intercensal in 2005 and Censo de Población y Vivienda in 2010. Therefore, these variables are relatively constant in the resulting dataset. We control for the homicide rate, given that we are explaining protests against crime. The average number of homicides per 100,000 inhabitants is 4.1 .

In Mexico, discontent with the security situation has motivated individuals to displace internally and internationally (Atuesta and Paredes 2016; Ríos 2014; Basu and Pearlman 2017), and security-motivated emigration likely deprives sending communities of those more critical of the government and, therefore, more likely to protest (Pfaff and Kim 2003; Kapur 2014). Emigration may, thus, reduce the incidence of protest if potential protesters are more likely to leave (Pfaff and Kim 2003; Kapur 2014). To account for this possibility, we control for emigration rates. ${ }^{10}$ This variable measures the percentage of households with emigrants in the five years previous to the survey collection period (INEGI).

\footnotetext{
${ }^{10}$ The correlation between the two variables is high but lower than might be expected $(0.54)$.
} 
As explained in Section 1, the literature on contentious mobilization has widely considered social networks to be important determinants of participation in social protests (Diani 1995; Friedman and McAdam 1992; Fujii 2008; Gould 1993; McAdam 1982, 1988; McAdam and Paulsen 1993; Passy 2001, 2002). In Section 1, we argued that the resource effect of remittances increases participation in informal risk-sharing networks of mutual help aimed at providing insurance against risks (Gallego and Mendola 2013; Mendola 2017). To our knowledge, there are no available data on informal social networks for which we can control; however, if we find that remittances have explanatory power after controlling for a variety of official organizations and other competing explanations, this finding will be suggestive evidence that remittances shape the likelihood of protesting through changes in households' incentives to organize informally against crime.

We control for the number of formal civil-society associations per 100,000 inhabitants. Following Ley (2014), we use the figures reported by the Mexican Interior Ministry's Register of Civil Society Organizations, which includes non-partisan, non-religious, and non-profit groups that are legally constituted and that may pursue a wide range of activities, from human rights defense to welfare provision. Because of the centrality of church associations in building tight local networks and stimulating political involvement (Smith 1996; Fransen 2015), we control for the number of these groups. Finally, trade unions have played important roles in social and political movements (Chenoweth and Ulfelder 2017, 305). Thus, we include a control for the number of labor unions and professional associations per 100,000 inhabitants. These three variables are taken from Mexico's economic census data (Ley 2014) and are expected to correlate positively with the likelihood of protesting.

As in Ley et al. (2019, 8-9), we control for the incumbent party in state government. In Mexican states governed by the national incumbent party during our study period (Partido de Acción Nacional, PAN), voters may have been better able to assign responsibility for growing 
insecurity (Ley 2017). However, criminal violence was higher in states governed by opposition parties, particularly the Partido de la Revolución Democrática, PRD, during the Calderón administration (Trejo and Ley 2016). We control for partisanship by including a dummy variable that equals 1 if the ruling party was from the opposition and 0 if the state was governed by the federal incumbent party (PAN).

Since we are using the level of remittances (logged), we control for the population (logged) of the state (INEGI). We also control for gross domestic product in constant 2008 pesos (logged) to distinguish the income effect of remittances from the income effect of initial wealth. Controlling for education (years of schooling) allows us to proxy the stock of human capital in the state at a given time. Additionally, we include the percentage of indigenous population in the state: these communities have had long traditions of strong formal and informal networks, as well as know-how for social collaboration, shared identities, solidarity, and resolution of collective action problems (Trejo 2009). Finally, we include a one-quarter lag of the dependent variable to control for possible inertia in protest activities.

\subsection{Empirical Strategy ${ }^{11}$}

Our empirical strategy at the state level exploits the quarter-to-quarter variation in remittances by state to estimate their association with protests against crime. Our specification takes the following form:

$$
\text { Protest }_{i t}=\beta_{0}+\alpha_{i}+\beta_{1} \ln \left(\text { remitt }_{i t}\right)+\beta_{2}\left[\ln \left(\text { remitt }_{i t}\right)\right]^{2}+\gamma_{1} X_{i t}+\varepsilon_{i t}
$$

\footnotetext{
${ }^{11}$ We closely follow the empirical strategy used in Ley et al.'s (2019) study on remittances and vigilantism in Mexico.
} 
for state $i$ and quarter $t$. The dependent variable, protest $_{i t}$, is a count variable measuring the number of protests that took place. In line with our argument, our main independent variable, remitt $_{i t}$, captures remittances in the recipient state (logged) in both linear and quadratic forms. $X_{i t}$ is a vector of socioeconomic, demographic, and political determinants of protests, $\alpha_{i}$ is a state-specific effect, and $\varepsilon_{i t}$ is the error term. ${ }^{12}$

Since the dependent variable is a count and the protest events are not independent, the most appropriate estimation technique is a negative binomial (NB) regression. Ignoring the data's temporal variation would yield less precise estimates. Given that some explanatory variables change slowly over time and that the study period is relatively short, the use of fixed effects is less viable (Allison and Waterman 2002; Ley 2014). Thus, we test for a negative binomial regression with random effects on a panel of 31 states.

It is possible that states with a larger number of protests and greater social unrest could experience a decline in remittance flows coming from abroad. Migrants may be reluctant to send remittances in contexts of rampant crime and insecurity due to uncertainty about financial security (Meseguer et al. 2017). In other words, reverse causality between protests and remittances must be accounted for. To address this endogeneity concern, we exploit an instrumental variable approach. The instrumental variable is constructed using two distinct data sources: i) quarterly US state unemployment rates (seasonally adjusted, end of period - U.S. Bureau of Labor Statistics 2006-2014) and ii) shares of the diaspora in the top 3 US states from each Mexican state, as of 2008 - based on matrículas emitidas - a document issued by consulates to registered Mexicans (Institute for Mexicans Abroad, IME).

This instrumental variable $Z_{i, t}$ for Mexican state $i$ in quarter $t$ multiplies the seasonally adjusted quarterly unemployment rate in US destination state $j$ at time $t, j=[1, \ldots, 4]$ by the share

\footnotetext{
${ }^{12}$ McKenzie and Rapoport (2007) also model an endogenous variable (migration) in quadratic form.
} 
of Mexican state $i$ 's diaspora residing in US state $j$, where $j$ identifies the top three US destination states and the United States as a whole. The intuition behind this variable is that Mexican states that have larger shares of migrants in US states and that experienced strong increases in unemployment saw remittance inflows decline, as is, in fact, the case: increases in unemployment in the destination have a negative impact on remittances sent back home. As far as the exogeneity condition goes, it is unlikely that the unemployment rate at the migrants' US destination will have a relationship with protests against crime in the Mexican sending state other than through its effect on remittances. While there could be some concern about matrículas being impacted by crime-induced emigration, by using data up to 2008, early in our research period, we can be reasonably confident that matrículas were not affected by crimeinduced emigration. Also, the IME 2008 data on consular matrículas are left without variation so that all time variation in the instrumental variable is due to fluctuations in employment at destination and not to changes in migration patterns (see Ambrosius and Meseguer 2020, 5, for a similar strategy). Our potentially endogenous variable of interest appears in the equation in linear and quadratic terms. We employ the so-called nonlinear in endogenous variables system of equations (Wooldridge, 2002) to estimate this specification.

\section{Results}

Table 2 reports the panel of negative binomial estimates of the independent variables' expected effects on the protest count. To control for more populated states being at higher risk of experiencing more protest activity, we use (log) population as the exposure variable in the model. In Column 1, the model includes remittances as a linear function only, and the coefficient is negative and significant. However, when we add the quadratic term (Column 2), the linear term turns positive and equally significant, while the quadratic term is negative and significant. We conducted a likelihood ratio (LR) test between Models 1 and 2 and are able to 
reject the null hypothesis that the additional term equals zero at the 1-percent level of significance. ${ }^{13}$ In other words, a non-linear relationship between protests and remittances provides a better fit.

$* * *$ Table 2 about here $* * *$

As expected, remittances have a positive effect on the expected protest count up to a certain level of remittance penetration, past which the impact decreases. Next, we calculated different specifications and introduced controls progressively in Columns 3-8. In the full specification in Column 8, increases in quarterly remittances, holding other predictors constant, are associated with increases in the difference in the log of expected counts of mobilizations against crime, with a decreasing effect after an inflection point at about 1.7 billion pesos. This figure happens to be slightly above the mean of state-quarterly remittances. Thus, remittances sent from abroad produce both an engagement and a disengagement effect when it comes to mobilizing citizens to collective action against crime. This finding shows that there is a false dichotomy when we theorize about remittances' effect on protest. Remittances can have either effect, depending on the largesse of the inflows. Only moderate to high levels of remittance inflows are "demobilizing." Figure 3 shows remittances' predicted effect on the expected protest count (based on Model 2). As expected, the relationship follows an inverted U-shape.

$$
* * * \text { Figure } 3 \text { about here } * * *
$$

\footnotetext{
${ }^{13}$ The LR statistic for Models 1 and 2 is 15.73 . The likelihood ratio test is also conducted for the full specification (Column 8), with and without the squared term of remittances. With an LR statistic of 6.71 , we are still able to reject the null hypothesis at the 1-percent level of significance.
} 
Therefore, our results indicate that for the average Mexican state, remittances may enable protests below the estimated threshold, while above 1.7 billion pesos, they discourage them. Considering the distribution of state-remittances by quarter (Figure 4) helps clarify the substantive meaning of these estimates: a low percentage of states receive high volumes of remittances, which means that in a majority of Mexican states, remittances could have an activation effect on the probability of protesting against crime.

$* * *$ Figure 4 about here $* * *$

Regarding control variables, we posited that emigration was more likely to deprive Mexican states of those most unsatisfied with the state of affairs, thus depressing protest. Our first finding backs this significant negative effect (Column 3), but it becomes insignificant as we include further controls. Not surprisingly, higher levels of crime proxied by crime rates increase the likelihood of protests at the state level consistently throughout all specifications.

Secondly, civil networks have explanatory power after we consider international financing of protests via remittances. This finding is very robust in the case of civil associations, confirming previous findings (Ley 2014). Indirectly, this result suggests that remittances' income effect on protest is likely to occur through the positive effect that remittances have on individual incentives to support informal social arrangements, on top of pre-existing formal networks of civil associations. Somewhat surprisingly, the number of church associations is negatively associated with protest counts, albeit with a very small effect. Note, however, that what our measure of religious density may be capturing is a proxy of religiosity, potentially associated with a more conservative reaction to crime and insecurity. It 
is likely that a more accurate measure to address the role that religious networks have on protest is religious competition, whereby different churches and religious leaders organize and compete to serve distinct but overlapping groups in the population (Trejo 2009). However, as Trejo (2009) shows, the dynamics of religious competition occur at the diocese or municipal level, and we lack corresponding data to test such a potential mechanism.

Thirdly, having an opposition party ruling the state does not increase the expected incidence of protests against crime. Fourth, states with higher average years of education exhibit higher expected numbers of protests, and, as expected, large shares of indigenous population are also associated with more protests. State wealth, while not statistically significant, does modify the size of the estimated effect of remittances on protests, suggesting that we need to control for subnational income levels. Finally, as Column 8 shows, the number of previous protests is positively, but not significantly, associated with contemporaneous protests after the rest of covariates are controlled for.

\section{Robustness $^{14}$}

Table 3 contains the instrumental variable approach results that provide evidence on the robustness of the estimated relationship. To address possible endogeneity issues stemming from our potentially endogenous variable of interest in both linear and quadratic terms, we adopt an instrumental variable approach (Wooldridge 2002) that is similar to a three-stage least squares estimation. The instrumental variable estimation is restricted to an OLS with random effects because the instrumental variable procedure implemented only holds when the system

\footnotetext{
${ }^{14}$ The procedure to deal with endogeneity closely follows the procedure in our study on remittances and vigilantism in Mexico (Ley et al. 2019, 13).
} 
of equations is linear in the parameters (Wooldridge 2002). The estimates for the threestepwise instrumental variable approach are reported in Table 3.

$$
\text { *** Table } 3 \text { about here } * * *
$$

In the first stage, Column 1, we regress the exogenous instrument of diaspora-weighted unemployment in the United States and the other exogenous covariates on remittances. ${ }^{15}$ The instrument is significantly associated with remittances: in line with theoretical expectations, rates of unemployment in migrants' destinations are negatively associated with remittances received. The linear prediction (fitted value) of remittances and its squared term from the previous stage are used as the excluded instruments in a 'two-stage least squares' estimation with two endogenous variables. We then have two additional first-stage regressions, one for each endogenous variable, and two instruments. ${ }^{16}$ Columns 2 and 3 in Table 3 have been labeled as 'second stage.' Note that these columns include the first-stage regressions of the two endogenous variables - namely, remittances and remittances squared. The linear predictions obtained in Column (1) are the excluded instruments (Pr[Remittances] and $\operatorname{Pr}\left[\right.$ Remittances $\left.\left.{ }^{2}\right]\right)$. We confirm their relevance separately in the equations for each endogenous regressor and jointly for the last stage.

The procedure's third step is shown in the last column (4) of Table 3, which gives the estimates of the second-stage regression (labeled as third stage) for the linear and quadratic effects of remittances on protests. The inverted U-shaped relationship between remittances and

\footnotetext{
${ }^{15}$ The Wald chi squared statistic indicates that we can reject the null hypothesis that the coefficients of the joint instruments in the reduced form equal zero.

${ }^{16}$ The equation is exactly identified; thus, we are unable to test for exogeneity.
} 
the protest count is robust to instrumenting the endogenous terms of remittances and remittances squared. The interpretation of these estimates is straightforward: a 10-percent increase in remittances is associated with an increase of 0.83 in the expected number of protests, holding everything else constant. We illustrate the inverted U-shape by calculating the predictive margins for specific values of the remittance distribution, keeping the rest of the covariates constant (Table 4).

\footnotetext{
*** Table 4 about here $* * *$
}

The predicted numbers of protests for different levels of remittances show a positive but decreasing effect. The expected number of protests increases from 0.448 protests at the $5^{\text {th }}$ percentile to 1.073 at the median value of remittances. After this level of quarterly state remittances, the predicted number of protests decreases to 0.919 (for the $75^{\text {th }}$ percentile) and drops further to 0.646 for states in the $95^{\text {th }}$ percentile of remittances. Thus, remittances increase the probability of protesting, but at a declining rate, which provides robust evidence that remittances sent from abroad produce both an engagement and a disengagement effect on protest against crime. ${ }^{17}$

Finally, we carried out a number of other robustness tests and controlled for multiple alternative explanations. First, the absolute volume of remittances may be hiding a state-size effect. To rule out this possibility, we estimated our main specification, using two alternative measures that capture the effect of remittance density on protests - namely, remittances per capita and the percentage of households receiving remittances at the state level (Online

\footnotetext{
${ }^{17}$ Another approach to instrument selection is to include higher-order terms of exogenous variables appearing in the system. We used this approach, and the main finding holds (Online Appendix Table A6).
} 
Appendix Table A2) ${ }^{18}$ Our result holds. We also included a quarterly indicator of economic activity (INEGI), instead of the yearly GDP, to match the periodicity of remittances (see Column 5 in Online Appendix Table A4). While the level of economic activity positively affects the likelihood of protesting, the inclusion of this control does not alter our main finding.

Second, we acknowledge that other types of crime, besides homicide rates, may influence protests. However, adding several crime variables in the same specification would only introduce multicollinearity, due to a high correlation among crime variables. Nonetheless, we provide an analysis of sensitivity to different crime measures, including the rate of disappearances and the rate of drug-related homicides separately (Online Appendix Table A3). All have the expected positive effect on protest, without affecting our main finding. Third, we controlled for inequality, which other authors have demonstrated to be an important determinant of violent protests in the form of vigilante organizations (Phillips 2017). Inequality is marginally relevant to explaining the incidence of protest (significant at 10 percent), but not consistent, and it does not alter our main finding (Online Appendix Table A4).

Fourth, remittances could potentially increase state capacity if, for instance, recipients demand more accountability and help reduce corruption (Burgess 2005; Tyburski 2014). This increase in state capacity, in turn, may reduce the motivation to protest. To address this possibility, we controlled for the number of libraries at the state level, following Phillips (2017), who notes that while the number of libraries is not a measure of state capacity in terms of security or the judicial apparatus, it is a good proxy for overall government capacity. Additionally, libraries are exogenous to security issues, which allows for a more accurate assessment. This variable turned out to be statistically insignificant and its inclusion does not affect our main finding (Online Appendix Table A4). Fifth, the very existence of self-defense

\footnotetext{
${ }^{18}$ We prefer our measure to one of normalizing by state wealth, which is not exogenous to remittances.
} 
organizations may correlate with the type of protests we explore here or even make protests against crime unnecessary to some extent. The presence of vigilante organizations does increase the probability of protest against crime, but including this variable does not alter our main result (Online Appendix Table A5).

Finally, while we controlled for various types of local formal networks, we also controlled for transnational migrant organizations, known as Hometown Associations (HTAs, Institute for Mexicans Abroad, IME). While the resources these organizations raise and invest in their communities (also known as collective remittances) are very small in comparison to the volume of individual remittances, these organizations bring organizational skills and experience to their communities (Burgess 2005; Duquette-Rury 2014; Bada 2016; PérezArmendáriz and Duquette-Rury 2019) that could well facilitate the organization of protests. HTAs do not seem to predict the protest count, and our main finding is robust to controlling for the number of existing HTAs in a given state (Online Appendix Table A5). ${ }^{19}$

\section{Discussion}

Workers' remittances help those left behind organize and protest against crime. Because they also improve recipients' living conditions, reduce economic risks, and improve perceptions of the security situation, however, remittances finance protests against crime at a declining rate. In other words, remittances provide resources to protest, but they also reduce the reasons to do so. This finding is relevant to several literatures. First, research on the international determinants of protests is only starting to pay attention to emigration and financial remittances (Barry et al. 2014; Miller and Ritter 2014; Escribà-Folch et al., 2018;

\footnotetext{
${ }^{19}$ Since information on these variables exist for only one year, the models including Vigilantes and HTAs are cross-sections of 31 states. As such, this evidence should be taken as preliminary.
} 
Germano 2018). In the literature on protests, resources are deemed essential for grievances to be transformed into collective action. Remittances provide resources to the senders' families and communities, which can then engage in collective action to protest against crime and insecurity. As such, this source of international flows should be systematically taken into consideration in future research on the international determinants of violent and non-violent protest.

Second, we contribute to the thriving literature on the political consequences of remittances. This literature has so far treated remittances as either causing political engagement or causing disengagement (Goodman and Hiskey 2008; Bravo 2009; Germano 2013, 2018; Pfutze 2014). We have added an important nuance to this finding by showing that remittances can cause both. As we demonstrated, remittances' impact on protests is not linear, and their positive effect on protest against crime declines in settings where remittances are slightly above average. Relying on recent scholarship (Adida and Girod 2011; Doyle 2015; Pfutze 2014; Fransen 2015), we have argued that this finding has to do with the income and substitution effects of remittances, which grant recipients more autonomy from the state, reduce grievances, and facilitate the formation of informal networks of mutual help. Informal networks and formal organizations have been behind the protest movement against crime studied in this article (Ley 2014; Durán-Martínez 2016; Dorff 2017). Interestingly, we find a similar non-linear effect of remittances on the probability of financing vigilante organizations at the municipal level in Mexico (Ley et al. 2019); but in the case of vigilantism, the tipping point after which remittances impacted the formation of self-defense organizations at a declining rate was located at a higher level of penetration at the municipal level. In other words, it takes large inflows of remittances to slow the formation of grass-root self-defense organizations. We interpret this finding as indicative that in comparison to non-violent protests, vigilantism is a more resourceintensive form of collective mobilization that requires greater and sustained financial support 
(Phillips 2017; Moncada 2017).

Future research should systematically explore remittances' impact on formal and informal civilian engagement. While some research on Mexico has investigated remittances' role in facilitating some forms of social networks (Duquete-Rury and Chen 2018), scholars have not yet made a consistent distinction between formal and informal networks. However, the fact that remittances retain explanatory power at the state level after controlling for a number of formal civil associations suggests that these inflows have been relevant in the spontaneous organization of mutual-help, risk-sharing networks, which have played a sizeable role in the protests we study here (Ley 2014).

Second, researchers should explore whether other types of migrant connectivity in the form of social remittances (Levitt 1998) also help those left behind mobilize to demand better protection and access to justice and to protest against crime and impunity. Research has shown that migrants often get familiar with, if not directly participate in, collective mobilization in their destinations (Pérez-Armendáriz and Crow 2010; Nikolova et al. 2017; Petrova 2019). This experience helps them become acquainted with different repertoires of collective action that can then be shared with relatives through transborder conversations with relatives back home (Pérez-Armendáriz and Crow 2010; Nikolova et al. 2017; Petrova 2019). Likely, the international transfer of norms also plays a role in the phenomenon we explore in this piece.

Finally, our findings should be tested in other instances of violent democracies to gain further external validity. Unfortunately, contexts of high crime and high remittance dependence in which to test our findings are abundant (Pérez-Armendáriz 2019), and these tests should figure at the top of this research agenda. All in all, our research calls attention to remittances as determinants of protest against crime and helps advance understandings of how remittances impact this particular example of non-electoral political activity. International networks of migrant solidarity with those left behind matter, as do the financial resources migrants send 
back home.

\section{References}

Adams, Richard H. and John Page. 2005. "Do International Migration and Remittances Reduce Poverty in Developing Countries?" World Development 33(10):1645-1669.

Adida, Claire L. and Desha M. Girod. 2011. "Do Migrants Improve their Hometowns? Remittances and Access to Public Services in Mexico, 1995-2000." Comparative Political Studies 44(1):3-27.

Ahmed, Azam. 2017. “In Mexico, Not Dead. Not Alive. Just Gone.” New York Times, November 20. https://www.nytimes.com/2017/11/20/world/americas/mexico-drug-wardead.html

Allison, Paul D. and Richard P Waterman. 2002. "Fixed-effects Negative Binomial Regression Models." Sociological Methodology 32(1):247-265.

Ambrosius, Christian. 2019. "Government Reactions to Private Substitutes for Public Goods. Remittances and the crowding-out of public finance." Journal of Comparative Economics, 47(2): 396-415.

Ambrosius, Christian and Covadonga Meseguer. 2020. "Return Migration, Crime, and Electoral Engagement Mexico." Electoral Studies, Online First, https://doi.org/10.1016/j.electstud.2020.102161

Atuesta, Laura H. and Dusan, Paredes. 2016 "Do Mexican Flee from Violence? The Effects of Drug-Related Violence on Migration Decisions in Mexico." Journal of Ethnic and Migration Studies 42 (3): 480-502.

Bada, Xóchitl. 2016. 'Collective Remittances and Development in Rural Mexico: A View from Chicago's Mexican Hometown Associations.' Population, Space and Place 22 (4): 343-55. https://doi.org/10.1002/psp.1958

Barry, Colin M., K. Chad Clay, Michael E. Flynn and Gregory Robinson. 2014. "Freedom of Foreign Movement, Economic Opportunities Abroad, and Protest in Non-Democratic Regimes." Journal of Peace Research 51(5):574-588.

Basu, Sukanya and Sarah Pearlman. 2017. 'Violence and Migration: Evidence from Mexico's Drug War.' IZA Journal of Development and Migration 7 (18): 1-29. https://doi.org/DOI $\underline{10.1186 / \mathrm{s} 40176-017-0102-6}$

Brady, Henry E., Sidney Verba and Kay Lehman Scholzman. 1995. "Beyond SES: A Resource Model of Political Participation." American Political Science Review 89(2):271-294.

Brancati, Dawn. 2014. "Pocketbook Protests: Explaining the Emergence of Pro-Democracy Protests Worldwide." Comparative Political Studies 47(11):1503-1530.

Bravo, Jorge. 2009. "Emigración y Compromiso Político en México.” Política y Gobierno, 1: 273-310. 
Brito, Steve, Ana Corbacho, René Osorio. 2014. "Remittances and the Impact of Crime in Mexico." Interamerican Development Bank, Working Paper Series, 514.

Burgess, Katrina. 2005. "Migrant Philanthropy and Local Governance in Mexico." Pp. 99-125 in New Patterns for Mexico: Remittances, Philanthropic Giving, and Equitable Development, edited by B. J. Merz. Cambridge, MA: Harvard

Cárdenas de Cosío, Ana. 2016. "The effect of the 'war on organised crime' on the Mexican federal judiciary: A comparative case study of judicial decision-making." Ph.D. Thesis, King's College London.

Chenoweth, Erica and Jay Ulferder. 2017. Can Structural Conditional Explain the Onset of Non-Violent Uprisings? Journal of Conflict Resolution, 61(2): 298-324.

Córdova, Abby, and Jonathan Hiskey. 2019. 'Development Context and the Political Behavior of Remittance Recipients in Latin America and the Caribbean.' Political Behavior, October. https://doi.org/10.1007/s11109-019-09574-5

DellaPorta, Donatella. 1988. Recruitment Processes in Clandestine Political Organizations: Italian Left-Wing Terrorism. In From Structure to Action: Comparing Social Movement Research Across Cultures, ed. Hanspeter Kriesi, Bert Klandersmans and Sidney Tarrow. JAI Press.

Diani, Mario. 1995. Green Networks. A Structural Analysis of the Italian Environmental Movement. Edinburgh University Press.

Dorff, Cassy. 2017. "Violence, Kinship Networks, and Political Resilience: Evidence from Mexico.” Journal of Peace Research, 54 (4): 558-573.

Doyle, David. 2015. "Remittances and Social Spending." American Political Science Review 109(4):785-802.

Doyle, David and Ana Isabel López. "Crime, Remittances, and Presidential Approval in Mexico." Journal of Ethnic and Migration Studies. Online First.

https://doi.org/10.1080/1369183X.2019.1623325

Duquette-Rury, Lauren. 2014. "Collective Remittances and Transnational Coproduction: The 3x1 Program for Migrants and Household Access to Public Goods in Mexico." Studies in Comparative International Development 49 (1): 112-139.

Duquette-Rury, Lauren, and Zhenxiang Chen. 2018. 'Does International Migration Affect Political Participation? Evidence from Multiple Data Sources across Mexican Municipalities, 1990-2013': International Migration Review, June. DOI:

https://doi.org/10.1177/0197918318774499

Durán-Martínez, Angélica. 2015. "To Kill and Tell? State Power, Criminal Competition, and Drug Violence.” Journal of Conflict Resolution 59(8): 1377-1402.

Durán-Martínez, Angélica. 2016. "Coping with danger and fear: organized civilian responses to violence in Mexico." Paper prepared for the Workshop on "Subnational Violence," CIDE, Mexico City, September 22.

Durand, Jorge, Emilio A Parrado, Douglas S. Massey. 1996. "Migradollars and Development: a Reconsideration of the Mexican Case." International Migration Review, 30 (2), 423-444. 
Escribà-Folch, Abel, Covadonga Meseguer and Joseph Wright. 2018. "Remittances and Protest in Autocracies." American Journal of Political Science,

https://onlinelibrary.wiley.com/doi/10.1111/ajps.12382

Fransen, Sonja. 2015. 'Remittances, Bonds and Bridges: Remittances and Social Capital in

Burundi.' The Journal of Development Studies 51 (10): 1294-1308. https://doi.org/10.1080/00220388.2015.1041517

Friedman, Debra and Doug McAdam. 1992. "Collective Identity and Activism: Networks, Choices, and the Life of a Social Movement." In Frontiers in Social Movement Theory, ed. Aldon D. Morris and Carol McClurg Mueller. New Haven: Yale University.

Fujii, Lee Ann. 2008. "The Power of Local Ties: Popular Participation in the Rwandan Genocide.” Security Studies 17(3):568-597.

Gallego, Juan M. and Mariapia Mendola. 2013. "Labour Migration and Social Networks Participation in Southern Mozambique." Economica 80(320): 721-759.

Gerber, Theodore P., and Karine Torosyan. 2013. 'Remittances in the Republic of Georgia: Correlates, Economic Impact, and Social Capital Formation.' Demography 50 (4): 1279-1301. https://doi.org/10.1007/s13524-013-0195-3

Germano, Roy. 2013. Migrants' Remittances and Economic Voting in the Mexican Countryside. Electoral Studies, 32(4), 875-885.

Germano, Roy. 2018. Outsourcing Welfare: How the Money Immigrants Send Home Contributes to Stability in Developing Countries. New York, NY: Oxford University Press.

Goodman, Gary L. and Jonathan Hiskey. 2008. "Exit without Leaving: Political Disengagement in High Migration Municipalities in Mexico." Comparative Politics 40(2):169188. 30 .

Gould, Roger V. 1993. "Collective Action and Network Structure." American Sociological Review 58:182-196.

Guerrero, Eduardo. 2018. "La segunda ola de violencia.” Nexos, April 1.

Gurr, Ted. 1970. Why Men Rebel. Princeton, NJ: Princeton University Press.

Human Rights Watch (HRW). 2011. Neither Rights Nor Security: Killings, Torture, and Disappearances in Mexico's War on Drugs. New York: Human Rights Watch. Available at: https://www.hrw.org/sites/default/files/reports/mexico1111webwcover 0.pdf

Human Rights Watch. 2013. Los Desaparecidos de México: El persistente costo de una crisis ignorada. Available at: https://www.hrw.org/es/report/2013/02/20/los-desaparecidos-demexico/el-persistente-costo-de-una-crisis-ignorada

Kapur, Devesh. 2014. "Political Effects of International Migration." Annual Review of Political Science 17:479-502.

Keck, Margaret and Kathryn Sikkink. 1998. Activist beyond borders. Advocacy networks in international politics. Ithaca: Cornell University Press. 
Khawaja, Marwan. 1994. "Resource mobilization, hardship, and popular collective action in the West Bank." Social Forces 73(1): 191-220.

Klandermans, Bert. 1997. The Social Psychology of Protest. Oxford: Blackwell.

Knox, Rupert. 2018. Social movements in support of the victims. Human rights and digital communications. In W. G. Pansters, B. T. Smith, and P. Watt (Eds.). Beyond the Drug War in Mexico. Human rights, the public sphere, and justice (pp. 126-143). Routledge. Taylor \& Francis Group.

Levitt, P. 1998. "Social Remittances: Migration Driven Local-Level Forms of Cultural Diffusion.” International Migration Review 32(4): 926-948.

Ley, Sandra. 2014. Citizens in Fear: Political Participation and Voting Behavior in the Midst of Violence. Ph.D. Thesis. Duke University.

Ley, Sandra. 2017. "Electoral Accountability in the Midst of Criminal Violence: Evidence from Mexico." Latin American Politics and Society 59(1): 3-27.

Ley, Sandra, José E. Ibarra-Olivo, and Covadonga Meseguer. 2019. "Vigilantism and Family Remittances," Journal of Ethnic and Migration Studies. Online First.

Loveman, Mara. 1998. "High-risk collective action: Defending human rights in Chile, Uruguay, and Argentina." American Journal of Sociology 104(2): 477-525.

McAdam, Doug. 1982. Political Process and the Development of Black Insurgency, 19301970. Chicago: University of Chicago Press.

McAdam, Doug. 1986. "Recruitment to High-Risk Activism: The Case of Freedom Summer." American Journal of Sociology 92(1):64-90.

McAdam, Doug and Ronelle Paulsen. 1993. "Specifying the Relationship Between Social Ties and Activism.” American Journal of Sociology 99:640-667.

McCarthy, John D. and Mayer N. Zald. 2002 "The Enduring Vitality of the Resource Mobilization Theory of Social Movements." In Jonathan H. Turner, ed. Handbook of Sociological Theory. New York: Kluwer Academic/Plenum publishers. pp. 553-565.

McCarthy, J.D., Wolfson, M., Baker, D.P., and Mosakowski, E. 1988. "The founding of social movement organizations: Local citizens' groups opposing drunken driving." In Ecological models of organizations. Cambridge, MA: Ballinger. pp. 71-84.

McKenzie, David and Hillel Rapoport. 2007. 'Network Effects and the Dynamics of Migration and Inequality: Theory and Evidence from Mexico.' Journal of Development Economics 84 (1): 1-24. https://doi.org/10.1016/j.jdeveco.2006.11.003

Mendola, Mariapia. 2017. "International Migration and Informal Social Protection in Rural Mozambique." Research in Economics, 71(2): 282-290.

Miller, Gina L. and Emily H. Ritter. 2014. "Emigrants and the Onset of of Civil War." Journal of Peace Research, 51(1): 51-64.

Moncada, Eduardo. 2017. "Varieties of vigilantism: conceptual discord, meaning and strategies." Global Crime 18(4): 403-423. 
Nikolova, Milena, Monica Roman, and Klaus F. Zimmermann. 2017. 'Left behind but Doing Good? Civic Engagement in Two Post-Socialist Countries.' Journal of Comparative Economics 45 (3): 658-684. DOI: https://doi.org/10.1016/j.jce.2016.04.006

Pansters, Wil G. 2018. "Drug trafficking, the informal order, and caciques. Reflections on the crime-governance nexus in Mexico." Global Crime, 19:3-4, 315-338

Pérez-Armendáriz, Clarisa. 2019. "Migrant Transnationalism in Violent Democracies." Journal of Ethnic and Migration Studies. Online First. DOI:

https://doi.org/10.1080/1369183X.2019.1623275

Pérez-Armendáriz, Clarisa and David Crow. 2010. "Do Migrants Remit Democracy? International Migration, Political Beliefs, and Behavior in Mexico." Comparative Political Studies 43(1):119-148.

Pérez-Armendáriz, Clarisa and Lauren Duquette-Rury. 2019. "The 3x1 Program for Migrants and Vigilante Groups in Mexico." Journal of Ethnic and Migration Studies. Online First. https://doi.org/10.1080/1369183X.2019.1623345

Petrova, Marina G. 2019. 'What Matters Is Who Supports You: Diaspora and Foreign States as External Supporters and Militants' Adoption of Nonviolence.' Journal of Conflict Resolution 63 (9): 2155-79. https://doi.org/10.1177/0022002719826645

Pfaff, Steven and Hyojoung Kim. 2003. "Exit-Voice Dynamics in Collective Action: An Analysis of Emigration and Protest in the East German Revolution." American Journal of Sociology, 109(2): 401-44.

Pfutze, Tobias. 2014. "Clientelism vs. Social Learning: The Electoral Effects of International Migration." International Studies Quarterly 58(2):295-307.

Phillips, Brian J. 2017. "Inequality and the Emergence of Vigilante Organizations: The Case of Mexican Autodefensas." Comparative Political Studies 50 (10):1358-89.

Pop-Eleches, Cristian, and Grigore Pop-Eleches. 2012. "Targeted Government Spending and Political Preferences.” Quarterly Journal of Political Science 7 (3): 285-320.

Putnam, Robert. 2000. Bowling Alone. New York: Simon and Schuster.

Reforma. 2013. "Tienen autodefensas en 68 municipios.” Reforma, Estados, March 2, p. 12.

Ríos, Viridiana. 2014. "The Role of Drug-Related Violence and Extortion in Promoting Mexican Migration: Unexpected Consequences of a Drug War." Latin American Research Review, 49(3): 199-217.

Shirk, David and Joel Walman. 2015. "Understanding Mexico's drug violence.” Journal of Conflict Resolution 59(8):1348-1376.

Smith, Christian. 1996. Disruptive Religion: The Force of Faith in Social Movement Activism. New York: Routledge

Smith, Michael P. and M. Bakker. 2008. Citizenship across Borders: The Political Transnationalism of el Migrante. Ithaca, NY: Cornell University Press. 
Smulovitz, Catalina, and Enrique Peruzzotti. 2000. "Societal Accountability in Latin America." Journal of Democracy 11(4): 147-158.

Tertytchnaya, Katerina, Catherine E. de Vries, Hector Solaz and David Doyle. 2018. American Political Science Review, 112(2):758-774.

Tyburski, Michael. D. 2014. "Curse or Cure? Migrant Remittances and Corruption." Journal of Politics, 76(3): 814-824.

Trejo, Guillermo. 2009. "Religious Competition and Ethnic Mobilization in Latin America: Why the Catholic Church Promotes Indigenous Movements in Mexico." American Journal of Political Science, 103(3): 323-342.

Trejo, Guillermo and Sandra Ley. 2016. "Federalism, drugs, and violence. Why intergovernmental partisan conflict stimulated inter-cartel violence in Mexico." Política y Gobierno 23(1): 9-52.

Trejo, Guillermo and Sandra Ley. 2018. "Why Did Drug Cartels Go to War in Mexico? Subnational Party Alternation, the Breakdown of Criminal Protection, and the Onset of LargeScale Violence." Comparative Political Studies 51(7): 900-937.

Trejo, Guillermo and Sandra Ley. 2019. "High-Profile Criminal Violence. Why Drug Cartels Murder Government Officials and Party Candidates in Mexico." British Journal of Political Science. DOI: https://doi.org/10.1017/S0007123418000637

White, Peter B., Dragana Vidovic, Belén González, Kristian S. Gleditsch, and David E. Cunningham. 2015. "Nonviolence as a Weapon of the Resourceful: From Claims to Tactics in Mobilization.” Mobilization 20(4): 471-91.

Wood, Elisabeth J. 2003. Collective Action and Civil War in El Salvador. Cambridge: Cambridge University Press.

Wooldridge, J. M. 2002. Econometric Analysis of Cross Section and Panel Data. Cambridge and London: MIT Press. https://doi.org/10.1515/humr.2003.021

World Bank. 2006. Global Economic Prospects: Economic Implications of Remittances and Migration. Washington, DC: World Bank.

World Health Organization (WHO). 2015. Homicides: Global Health Statistics. Available at http://apps.who.int/violence-info/homicide/

Yang, Dean and HwaJung Choi. 2007. "Are Remittances Insurance? Evidence from Rainfall Shocks in the Philippines." The World Bank Economic Review 21: 219-48.

Zárate-Hoyos, Germán. 2005. "The Development Impact of Migrant Remittances in Mexico.” In Ferri, Donald F. and Steven R. Wilson (ed), Beyond Small Change. Making Remittances Count 159-192, Washington, D.C.: Interamerican Development Bank. 


\section{FIGURES}

Figure 1. Protest Against Crime, Count by State, 2006/1-2011/2

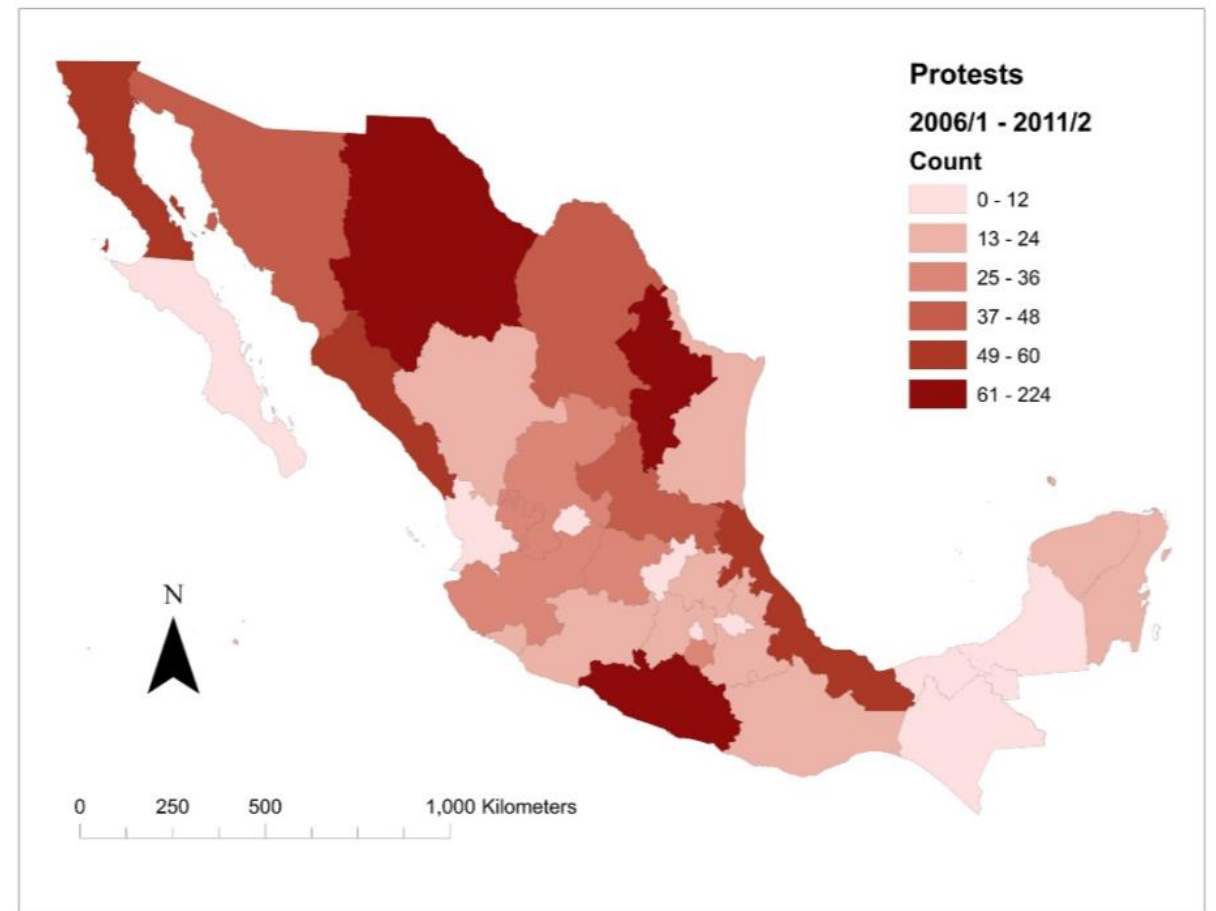

Source: Authors, with data from Mexican Protest Against Crime (MPC) Dataset (Ley, 2014).

Figure 2. Average Remittances by State, 2006/1-2011/2

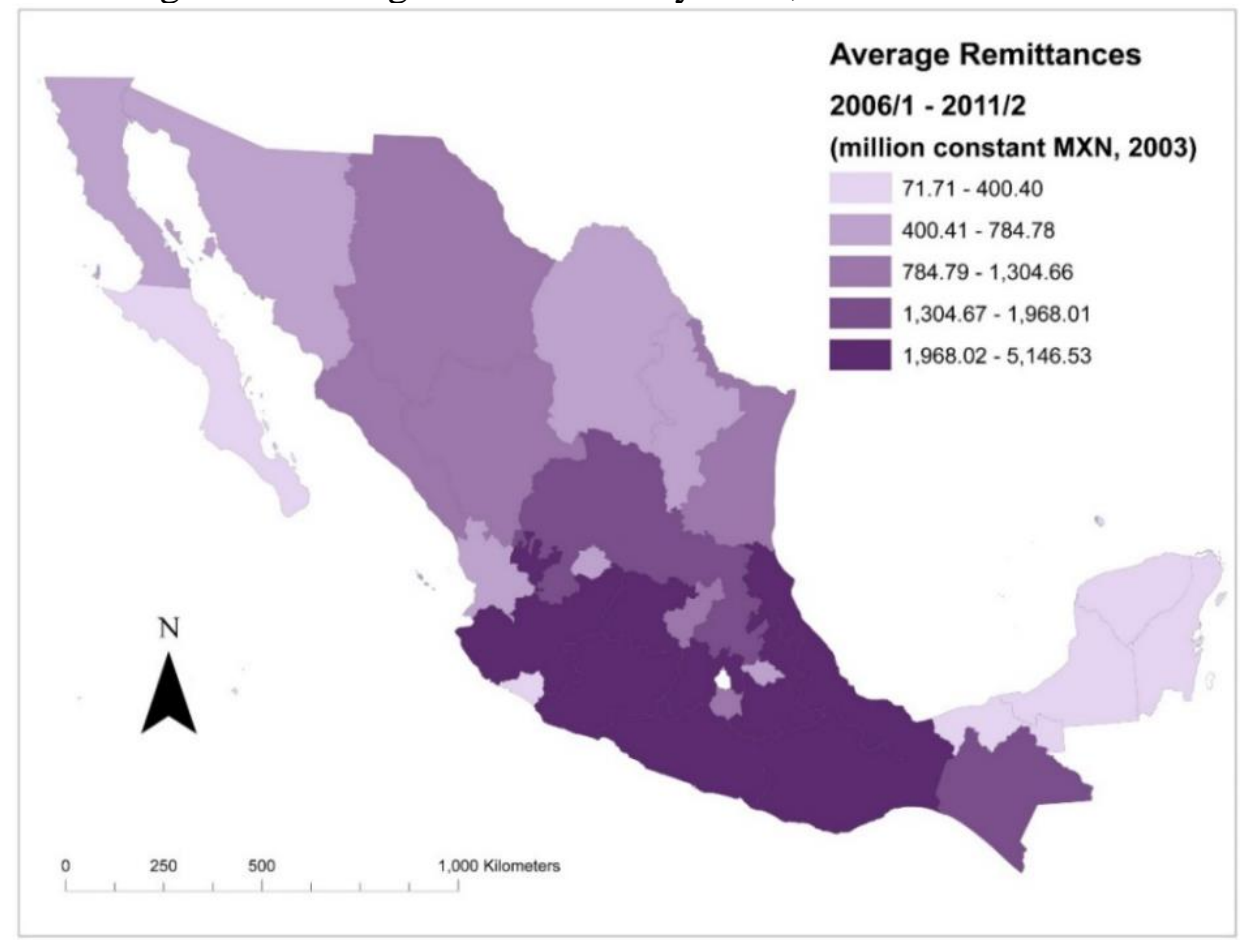


Figure 3. Predicted non-linear effect of remittances on expected count of protests

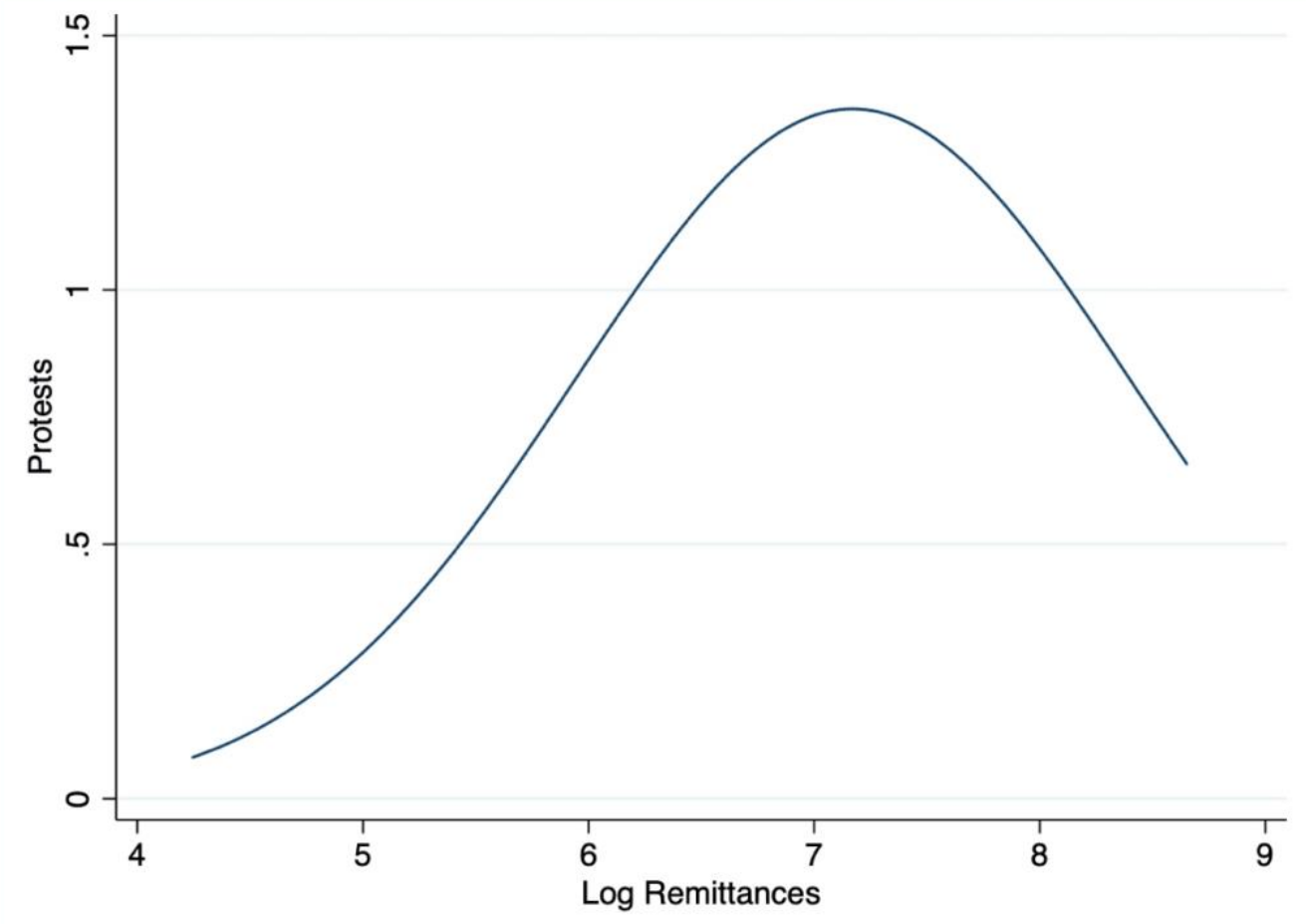

Figure 4. Distribution of quarterly remittances

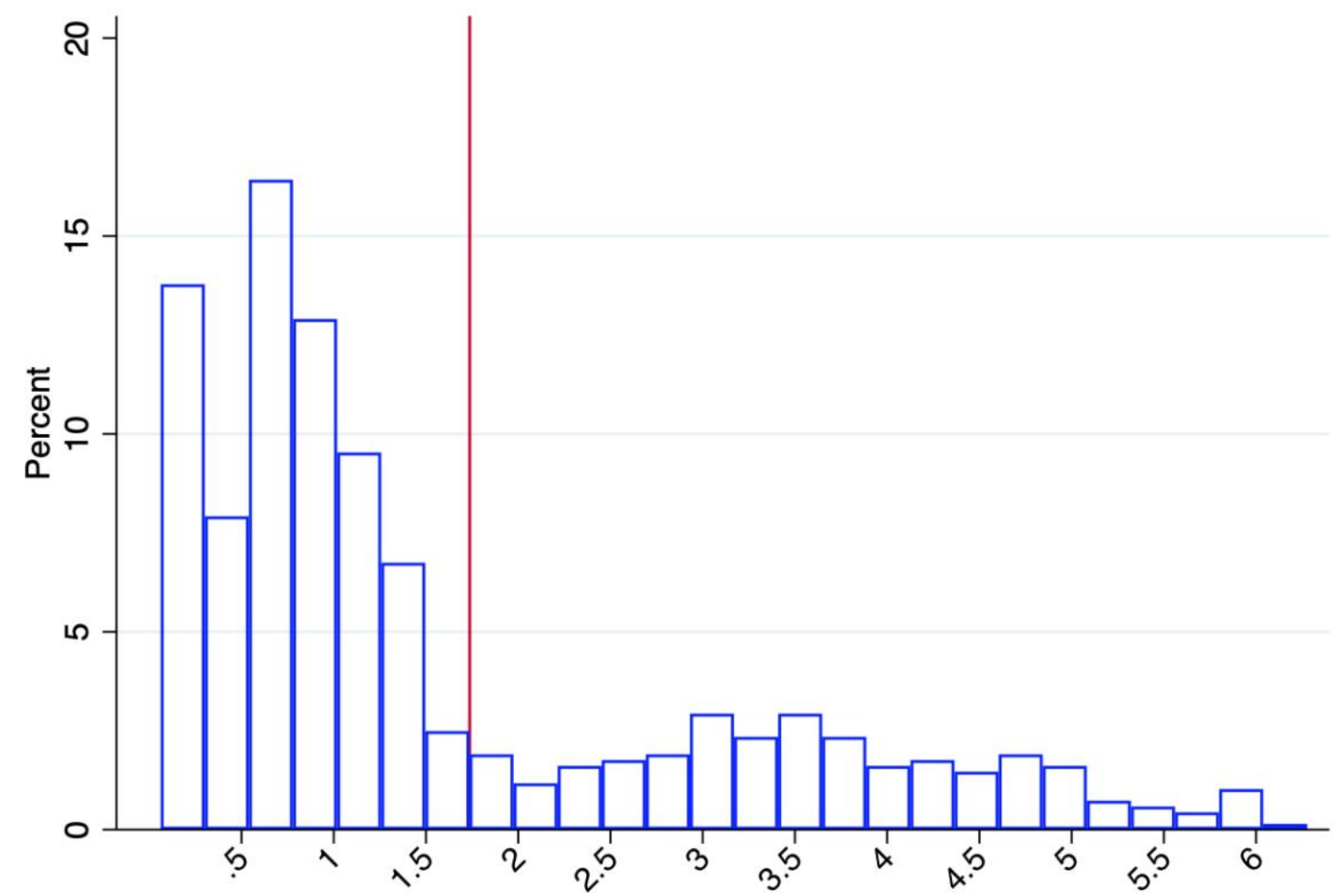

Remittances in constant pesos 2003 (billion) 


\section{TABLES}

Table 1. Protests against Crime and Remittances: Summary Statistics

\begin{tabular}{|c|c|c|c|c|c|}
\hline VARIABLES & $\begin{array}{l}\text { (1) } \\
\mathrm{N}\end{array}$ & $\begin{array}{c}(2) \\
\text { mean }\end{array}$ & $\begin{array}{l}(3) \\
\text { SD } \\
\end{array}$ & $\begin{array}{c}(4) \\
\text { Min }\end{array}$ & $\begin{array}{c}(5) \\
\operatorname{Max} \\
\end{array}$ \\
\hline \multicolumn{6}{|l|}{ Protests } \\
\hline Number of protests ${ }^{q}$ & 682 & 1.078 & 2.604 & 0 & 29 \\
\hline \multicolumn{6}{|l|}{ Remittances } \\
\hline Remittances $^{\mathrm{q}}$ & 682 & 1,618 & 1,486 & 61.97 & 6,277 \\
\hline Log Remittances ${ }^{q}$ & 682 & 6.923 & 1.051 & 4.127 & 8.745 \\
\hline \multicolumn{6}{|l|}{ Controls } \\
\hline Emigration $^{5 y}$ & 682 & 3.834 & 2.908 & 0.446 & 12.18 \\
\hline Log Population ${ }^{5 y}$ & 682 & 14.68 & 0.744 & 13.15 & 16.54 \\
\hline Average years of schooling ${ }^{5 y}$ & 682 & 6.900 & 0.962 & 4.992 & 9.020 \\
\hline Share of indigenous population ${ }^{5 y}$ & 682 & 0.104 & 0.136 & 0.002 & 0.542 \\
\hline Opposition party in state government $\mathrm{t}^{\mathrm{q}}$ & 682 & 0.756 & 0.428 & 0 & 1 \\
\hline Homicide rate ${ }^{\mathrm{q}}$ & 682 & 4.148 & 5.912 & 0.0466 & 58.54 \\
\hline Unions $^{\mathrm{y}}$ & 682 & 112.5 & 82.27 & 33 & 530.7 \\
\hline Civil associations $^{\mathrm{y}}$ & 682 & 224.6 & 161.6 & 40 & 1,025 \\
\hline Churches $^{y}$ & 682 & 1,736 & 1,171 & 272.0 & 5,873 \\
\hline Log GDP per capita ${ }^{y}$ & 682 & 12.40 & 0.732 & 11.05 & 13.91 \\
\hline \multicolumn{6}{|l|}{ Instrument } \\
\hline Weighted US unemployment rates $\mathrm{q}$ & 682 & 7.420 & 2.512 & 4.082 & 11.72 \\
\hline
\end{tabular}

Notes: The superscripts on each variable indicate the level of variation: quarterly ${ }^{\mathrm{q}}$, yearly ${ }^{\mathrm{y}}$, or 5 -years ${ }^{5 \mathrm{y}}$ 
Table 2. Protest and Remittances: Negative Binomial Random Effects by Quarter.

\begin{tabular}{|c|c|c|c|c|c|c|c|c|}
\hline Dep. Var. Protests & $(1)$ & $(2)$ & $(3)$ & $(4)$ & $(5)$ & $(6)$ & $(7)$ & $(8)$ \\
\hline Log(remittances) & $\begin{array}{c}-0.3205 * * * \\
(0.119)\end{array}$ & $\begin{array}{c}4.5368 * * * \\
(1.285)\end{array}$ & $\begin{array}{c}4.5247 * * * \\
(1.366)\end{array}$ & $\begin{array}{c}4.2227 * * * \\
(1.294)\end{array}$ & $\begin{array}{c}3.4262 * * * \\
(1.323)\end{array}$ & $\begin{array}{c}3.4735^{* * * *} \\
(1.333)\end{array}$ & $\begin{array}{c}4.3534 * * * \\
(1.533)\end{array}$ & $\begin{array}{c}4.2970 * * * \\
(1.518)\end{array}$ \\
\hline $\log (\text { remittances })^{2}$ & & $\begin{array}{c}-0.3493 * * * \\
(0.092)\end{array}$ & $\begin{array}{c}-0.3344 * * * \\
(0.098)\end{array}$ & $\begin{array}{c}-0.3198 * * * \\
(0.092)\end{array}$ & $\begin{array}{c}-0.2444 * * \\
(0.096)\end{array}$ & $\begin{array}{c}-0.2462 * * \\
(0.097)\end{array}$ & $\begin{array}{c}-0.2881 * * * \\
(0.110)\end{array}$ & $\begin{array}{c}-0.2880 * * * \\
(0.108)\end{array}$ \\
\hline Emigration & & & $\begin{array}{c}-0.0991 * * * \\
(0.037)\end{array}$ & $\begin{array}{r}-0.0393 \\
(0.036)\end{array}$ & $\begin{array}{c}-0.0899 * * \\
(0.041)\end{array}$ & $\begin{array}{c}-0.0926^{* *} \\
(0.041)\end{array}$ & $\begin{array}{r}-0.0189 \\
(0.052)\end{array}$ & $\begin{array}{r}-0.0147 \\
(0.051)\end{array}$ \\
\hline Homicide rate & & & & $\begin{array}{c}0.0450 * * * \\
(0.006)\end{array}$ & $\begin{array}{c}0.0408 * * * \\
(0.007)\end{array}$ & $\begin{array}{c}0.0405 * * * \\
(0.007)\end{array}$ & $\begin{array}{c}0.0413 * * * \\
(0.007)\end{array}$ & $\begin{array}{c}0.0397 * * * \\
(0.008)\end{array}$ \\
\hline Civil associations & & & & & $\begin{array}{c}0.0026 * * * \\
(0.001)\end{array}$ & $\begin{array}{c}0.0027 * * * \\
(0.001)\end{array}$ & $\begin{array}{c}0.0022 * * * \\
(0.001)\end{array}$ & $\begin{array}{c}0.0018 * * \\
(0.001)\end{array}$ \\
\hline Unions & & & & & $\begin{array}{l}0.0004 \\
(0.002)\end{array}$ & $\begin{array}{l}0.0003 \\
(0.002)\end{array}$ & $\begin{array}{l}0.0012 \\
(0.002)\end{array}$ & $\begin{array}{l}0.0014 \\
(0.002)\end{array}$ \\
\hline Churches & & & & & $\begin{array}{c}-0.0006 * * * \\
(0.000)\end{array}$ & $\begin{array}{c}-0.0007 * * * \\
(0.000)\end{array}$ & $\begin{array}{c}-0.0007 * * * \\
(0.000)\end{array}$ & $\begin{array}{c}-0.0007 * * * \\
(0.000)\end{array}$ \\
\hline Opposition party & & & & & & $\begin{array}{r}0.1614 \\
(0.190)\end{array}$ & $\begin{array}{c}0.3876 * \\
(0.219)\end{array}$ & $\begin{array}{c}0.2837 \\
(0.218)\end{array}$ \\
\hline Average schooling & & & & & & & $\begin{array}{c}0.6697 * * \\
(0.266)\end{array}$ & $\begin{array}{c}0.5940 * * \\
(0.256)\end{array}$ \\
\hline Indigenous population & & & & & & & $\begin{array}{l}0.0320 * \\
(0.017)\end{array}$ & $\begin{array}{c}0.0295^{*} \\
(0.016)\end{array}$ \\
\hline $\log (\mathrm{GDP})$ & & & & & & & $\begin{array}{l}0.1332 \\
(0.255)\end{array}$ & $\begin{array}{l}0.1252 \\
(0.250)\end{array}$ \\
\hline Lagged protest & & & & & & & & $\begin{array}{l}0.0120 \\
(0.014)\end{array}$ \\
\hline Observations & 682 & 682 & 682 & 682 & 682 & 682 & 682 & 651 \\
\hline Number of states & 31 & 31 & 31 & 31 & 31 & 31 & 31 & 31 \\
\hline Log likelihood & -851.3 & -843.4 & -839.7 & -823.4 & -813.7 & -813.3 & -809.6 & -787.3 \\
\hline
\end{tabular}

Notes: Robust standard errors (observed information matrix, OIM) in parentheses. ${ }^{* * *} \mathrm{p}<0.01,{ }^{*} \mathrm{p}<0.05,{ }^{*} \mathrm{p}<0.1$ 
Table 3. Protest and Remittances: Instrumental Variables

\begin{tabular}{|c|c|c|c|c|}
\hline Dep. Var. Protests & $\begin{array}{c}\text { first stage } \\
(1) \\
\end{array}$ & $\begin{array}{c}\text { second stage } \\
\text { Remittances } \\
\text { (2) }\end{array}$ & $\begin{array}{c}\text { second stage } \\
\text { Remittances } \\
(3) \\
\end{array}$ & $\begin{array}{c}\text { third stage } \\
\text { Protest } \\
(4) \\
\end{array}$ \\
\hline $\log ($ remittances $)$ & & & & $\begin{array}{c}9.0438 * * \\
(4.547)\end{array}$ \\
\hline $\log (\text { remittances })^{2}$ & & & & $\begin{array}{c}-0.2802 * * \\
(0.138)\end{array}$ \\
\hline Emigration & $\begin{array}{c}-0.0190 * * * \\
(0.007)\end{array}$ & $\begin{array}{c}0.1042 * * * \\
(0.007)\end{array}$ & $\begin{array}{c}1.4502 * * * \\
(0.101)\end{array}$ & $\begin{array}{c}-0.5097 * \\
(0.298)\end{array}$ \\
\hline Homicide rate & $\begin{array}{c}0.0031^{*} \\
(0.002)\end{array}$ & $\begin{array}{c}-0.0000 \\
(0.003)\end{array}$ & $\begin{array}{r}-0.0174 \\
(0.041)\end{array}$ & $\begin{array}{c}0.2248^{* * * *} \\
(0.060)\end{array}$ \\
\hline Civil associations & $\begin{array}{l}0.0001 \\
(0.000)\end{array}$ & $\begin{array}{c}0.0007 * * * \\
(0.000)\end{array}$ & $\begin{array}{c}0.0099 * * * \\
(0.002)\end{array}$ & $\begin{array}{r}-0.0030 \\
(0.002)\end{array}$ \\
\hline Unions & $\begin{array}{r}-0.0013 \\
(0.001)\end{array}$ & $\begin{array}{c}0.0015^{* * * *} \\
(0.000)\end{array}$ & $\begin{array}{c}0.0213 * * * \\
(0.004)\end{array}$ & $\begin{array}{r}-0.0039 \\
(0.003)\end{array}$ \\
\hline Churches & $\begin{array}{c}-0.0000 \\
(0.000)\end{array}$ & $\begin{array}{c}-0.0002 * * * \\
(0.000)\end{array}$ & $\begin{array}{c}-0.0023 * * * \\
(0.000)\end{array}$ & $\begin{array}{l}0.0009 \\
(0.001)\end{array}$ \\
\hline Opposition party & $\begin{array}{c}-0.0729 * * \\
(0.028)\end{array}$ & $\begin{array}{c}-0.0607^{*} \\
(0.031)\end{array}$ & $\begin{array}{c}-0.9063^{* *} \\
(0.429)\end{array}$ & $\begin{array}{l}0.3518 \\
(0.341)\end{array}$ \\
\hline Average schooling & $\begin{array}{c}-0.3181^{* * * *} \\
(0.042)\end{array}$ & $\begin{array}{c}-0.1244 * * \\
(0.054)\end{array}$ & $\begin{array}{c}-1.8428 * * * \\
(0.700)\end{array}$ & $\begin{array}{l}1.3951^{*} \\
(0.805)\end{array}$ \\
\hline Indigenous population & $\begin{array}{c}-0.0222 * * * \\
(0.008)\end{array}$ & $\begin{array}{c}-0.0020 \\
(0.004)\end{array}$ & $\begin{array}{c}-0.0310 \\
(0.051)\end{array}$ & $\begin{array}{c}0.0679 * \\
(0.039)\end{array}$ \\
\hline Log (population) & $\begin{array}{c}1.3244 * * * \\
(0.157)\end{array}$ & $\begin{array}{c}0.7236 * * * \\
(0.230)\end{array}$ & $\begin{array}{c}10.9862 * * * \\
(2.877)\end{array}$ & $\begin{array}{c}-7.1600 * \\
(4.198)\end{array}$ \\
\hline $\log (\mathrm{GDP})$ & $\begin{array}{l}-0.3449 \\
(0.222)\end{array}$ & $\begin{array}{c}-0.3258 * * * \\
(0.073)\end{array}$ & $\begin{array}{c}-4.8733 * * * \\
(0.912)\end{array}$ & $\begin{array}{c}2.7278^{*} \\
(1.536)\end{array}$ \\
\hline Lagged protest & $\begin{array}{r}-0.0020 \\
(0.002)\end{array}$ & $\begin{array}{c}-0.0120^{* *} \\
(0.006)\end{array}$ & $\begin{array}{c}-0.1456^{*} \\
(0.080)\end{array}$ & $\begin{array}{c}0.2824 * * \\
(0.110)\end{array}$ \\
\hline IV Unemployment & $\begin{array}{c}-0.0416 * * * \\
(0.006)\end{array}$ & & & \\
\hline $\operatorname{Pr}[\log ($ remittances $)]$ & & $\begin{array}{c}-0.1026 \\
(0.246)\end{array}$ & $\begin{array}{c}-17.0580 * * * \\
(2.893)\end{array}$ & \\
\hline $\operatorname{Pr}\left[\log (\text { remittances })^{2}\right]$ & & $\begin{array}{c}0.0415 * * * \\
(0.015)\end{array}$ & $\begin{array}{c}1.6569 * * * \\
(0.161)\end{array}$ & \\
\hline R-squared & 0.798 & 0.917 & 0.921 & 0.050 \\
\hline Wald Chi2 & 700.3 & - & - & - \\
\hline $\mathrm{F}$ & - & 7.38 & 55.15 & - \\
\hline Sanderson-Windmeijer F & - & 9.70 & 17.24 & - \\
\hline Sanderson-Windmeijer Chi2 & - & 9.92 & 17.62 & - \\
\hline Kleibergen-Paap rk LM & - & - & - & 8.429 \\
\hline Kleibergen-Paap rk Wald F & - & - & - & 5.360 \\
\hline Observations & 651 & 651 & 651 & 651 \\
\hline
\end{tabular}

Robust standard errors in parentheses $* * * \mathrm{p}<0.01, * * \mathrm{p}<0.05, * \mathrm{p}<0$. The $\mathrm{F}$ tests of excluded instruments are reasonably high, reassuring us of the relevance of our instruments. The Sanderson-Windmeijer F statistic confirms that the parameters are not weakly identified. The SandersonWindmeijer chi-squared Wald statistics rejects the null hypothesis that the endogenous parameter is under-identified. We also test the null hypothesis that our two excluded instruments are redundant, and we reject the null hypothesis at the 1 percent level of significance. KleibergenPaap LM statistic rejects the null that the model is under-identified. Kleibergen-Paap rk Wald F tells us that the equation is not weakly identified. 
Table 4. Predicted Number of Protests

Percentile of remittances Fitted value of protests

$\begin{array}{cc}5^{\text {th }} & 0.448 \\ 25^{\text {th }} & 1.031 \\ \text { Median } & 1.073 \\ 75^{\text {th }} & 0.919 \\ 95^{\text {th }} & 0.646\end{array}$




\section{Online Appendix}

Figure A1. Quarterly variation of remittances to Mexico

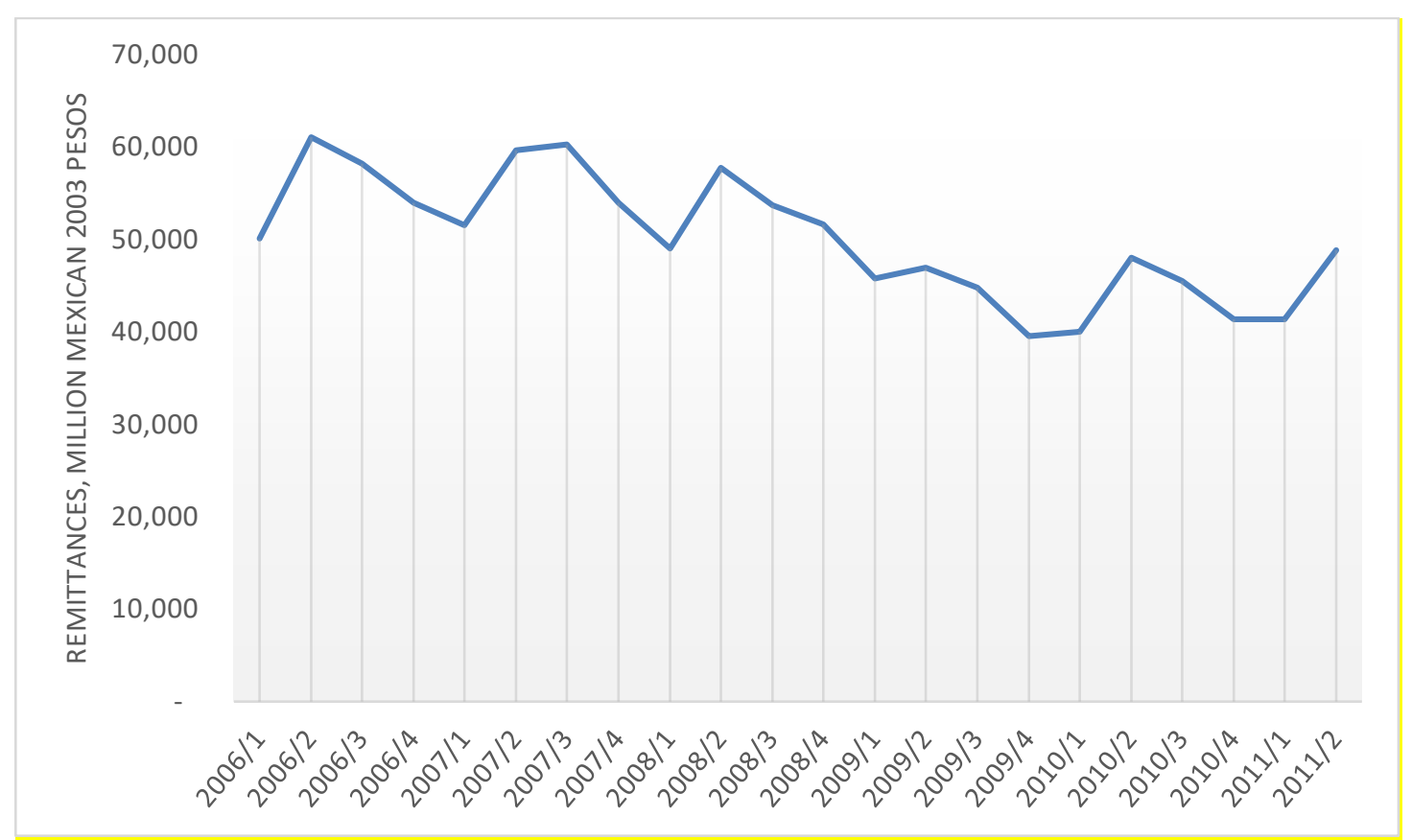

Source: Authors' own elaboration on data from Nyblade and O’Mahony (2014) 
Table A1. List of newspapers used for the MSD dataset

\begin{tabular}{|c|c|c|}
\hline State & Newspaper & Years \\
\hline Aguascalientes & El Sol de Aguascalientes & $2008-2012$ \\
\hline \multirow[t]{3}{*}{ Baja California } & Frontera & 2006-2008 \\
\hline & Crónica & 2009 \\
\hline & El Vigía & 2010-2012 \\
\hline Baja California Sur & El Sudcaliforniano & $2006-2012$ \\
\hline \multirow[t]{2}{*}{ Coahuila } & El Siglo de Torreón & $2006-2012$ \\
\hline & El Zócalo de Saltillo & $2006-2012$ \\
\hline Colima & Diario de Colima & $2006-2012$ \\
\hline Chihuahua & The Chihuahua News Database, provided by Información Procesada(INPRO) & $2006-2012$ \\
\hline \multirow[t]{2}{*}{ Durango } & El Siglo de Durango & 2006-2012 \\
\hline & El Sol de Durango & $2008-2012$ \\
\hline \multirow[t]{2}{*}{ Guanajuato } & Periódico AM & 2006-2012 \\
\hline & Milenio León & 2006-2012 \\
\hline \multirow[t]{2}{*}{ Guerrero } & El Sur & 2006-2012 \\
\hline & El Sol de Acapulco & $2008-2012$ \\
\hline \multirow[t]{2}{*}{ Hidalgo } & El Sol de Hidalgo & 2006-2012 \\
\hline & Milenio Pachuca & $2006-2012$ \\
\hline \multirow[t]{2}{*}{ Jalisco } & El Mural & $2006-2012$ \\
\hline & El Informador & $2006-2012$ \\
\hline México & Milenio Estado de México & $2006-2012$ \\
\hline \multirow[t]{2}{*}{ Michoacán } & El Sol de Morelia & $2008-2012$ \\
\hline & Cambio & 2009-2012 \\
\hline \multirow[t]{2}{*}{ Morelos } & El Sol de Cuernavaca & $2008-2012$ \\
\hline & La Unión & $2007-2012$ \\
\hline \multirow[t]{2}{*}{ Nuevo León } & El Norte & 2006-2012 \\
\hline & El Porvenir & $2006-2012$ \\
\hline \multirow[t]{2}{*}{ Puebla } & El Sol de Puebla & $2006-2012$ \\
\hline & Milenio Puebla & $2006-2012$ \\
\hline Querétaro & Diario de Querétaro & $2006-2012$ \\
\hline \multirow[t]{2}{*}{ San Luis Potosí } & El Sol de San Luis & 2006-2012 \\
\hline & La Jornada de San Luis & $2006-2012$ \\
\hline \multirow[t]{2}{*}{ Sinaloa } & El Sol de Sinaloa & $2008-2012$ \\
\hline & Noroeste & $2008-2012$ \\
\hline Sonora & El Imparcial & 2006-2012 \\
\hline Tabasco & Milenio Villahermosa & $2006-2012$ \\
\hline \multirow[t]{3}{*}{ Tamaulipas } & El Sol de Tamaulipas & $2008-2012$ \\
\hline & El Mañana & 2009-2012 \\
\hline & Milenio Tampico & 2006-2012 \\
\hline Tlaxcala & El Sol de Tlaxcala & $2008-2012$ \\
\hline \multirow[t]{5}{*}{ Veracruz } & El Sol de Orizaba & $2008-2012$ \\
\hline & El Sol de Córdoba & $2008-2012$ \\
\hline & Milenio Xalapa & $2006-2012$ \\
\hline & Liberal & $2008-2012$ \\
\hline & La Jornada Veracruz & $2011-2012$ \\
\hline Yucatán & Diario de Yucatán & $2006-2012$ \\
\hline \multirow[t]{3}{*}{ Zacatecas } & El Sol de Zacatecas & $2008-2012$ \\
\hline & Imagen & 2006-2007 \\
\hline & NTR & 2008-2012 \\
\hline National newspaper & Reforma & 2006-2012 \\
\hline
\end{tabular}


Table A2. Protest and Remittances: Negative Binomial with density of remittance penetration measured in per capita terms and as the \% of households receiving remittances at the state level.

\begin{tabular}{|c|c|c|}
\hline Dep. Var. Protests & $\begin{array}{c}\text { Remittances per } \\
\text { capita } \\
(1)\end{array}$ & $\begin{array}{c}\text { \% of households } \\
\text { with remittances } \\
(2)\end{array}$ \\
\hline Density of remittances & $\begin{array}{c}0.0036 * * \\
(0.001)\end{array}$ & $\begin{array}{c}0.3169 * * * \\
(0.091)\end{array}$ \\
\hline Density of remittances ${ }^{2}$ & $\begin{array}{c}-0.000002^{*} \\
(0.000)\end{array}$ & $\begin{array}{c}-0.0107 * * \\
(0.005)\end{array}$ \\
\hline Emigration & $\begin{array}{r}-0.0629 \\
(0.059)\end{array}$ & $\begin{array}{c}-0.0559 \\
(0.051)\end{array}$ \\
\hline Homicide rate & $\begin{array}{c}0.0399 * * * \\
(0.008)\end{array}$ & $\begin{array}{c}0.0364 * * * \\
(0.008)\end{array}$ \\
\hline Civil associations & $\begin{array}{c}0.0024 * * * \\
(0.001)\end{array}$ & $\begin{array}{l}0.0011 \\
(0.001)\end{array}$ \\
\hline Unions & $\begin{array}{l}0.0002 \\
(0.002)\end{array}$ & $\begin{array}{l}0.0006 \\
(0.002)\end{array}$ \\
\hline Churches & $\begin{array}{c}-0.0006 * * \\
(0.000)\end{array}$ & $\begin{array}{l}-0.0000 \\
(0.000)\end{array}$ \\
\hline Opposition party & $\begin{array}{l}0.3195 \\
(0.230)\end{array}$ & $\begin{array}{l}0.1290 \\
(0.210)\end{array}$ \\
\hline Average schooling & $\begin{array}{c}0.6290 * * \\
(0.259)\end{array}$ & $\begin{array}{c}0.4818^{* *} \\
(0.223)\end{array}$ \\
\hline $\log (\mathrm{GDP})$ & $\begin{array}{l}0.4309 \\
(0.330)\end{array}$ & $\begin{array}{c}0.5925^{* *} \\
(0.238)\end{array}$ \\
\hline Indigenous population & $\begin{array}{l}0.0249 \\
(0.017)\end{array}$ & $\begin{array}{c}0.0258^{*} \\
(0.015)\end{array}$ \\
\hline Lagged protest & $\begin{array}{l}0.0122 \\
(0.015)\end{array}$ & $\begin{array}{l}0.0095 \\
(0.014)\end{array}$ \\
\hline $\begin{array}{l}\text { Observations } \\
\text { Number of states } \\
\text { Log likelihood }\end{array}$ & $\begin{array}{c}651 \\
31 \\
-788.7\end{array}$ & $\begin{array}{c}651 \\
31 \\
-787.9\end{array}$ \\
\hline
\end{tabular}

Notes: Robust standard errors (OIM) in parentheses. $* * * \mathrm{p}<0.01, * * \mathrm{p}<0.05, * \mathrm{p}<0.1$. The variable percentage of households receiving remittances is taken from Censos de Población y Vivienda, INEGI. 
Table A3. Protest and Remittances: Negative Binomial sensitivity to different crime measures

(1) (2) (3) (4)

\begin{tabular}{|c|c|c|c|c|}
\hline Dep. Var. Protests & Homicides & Drug-related Homicides & Disappearances & Num. Cartels \\
\hline Log(remittances) & $\begin{array}{c}4.2970^{* * * *} \\
(1.518)\end{array}$ & $\begin{array}{c}4.2969 * * * \\
(1.552)\end{array}$ & $\begin{array}{c}4.2549 * * * \\
(1.583)\end{array}$ & $\begin{array}{c}4.4165^{* * * *} \\
(1.510)\end{array}$ \\
\hline $\log (\text { remittances })^{2}$ & $\begin{array}{c}-0.2880 * * * * \\
(0.108)\end{array}$ & $\begin{array}{c}-0.2857 * * * \\
(0.111)\end{array}$ & $\begin{array}{c}-0.2748^{* *} \\
(0.113)\end{array}$ & $\begin{array}{c}-0.3033^{* * * *} \\
(0.109)\end{array}$ \\
\hline Emigration & $\begin{array}{r}-0.0147 \\
(0.051)\end{array}$ & $\begin{array}{r}-0.0146 \\
(0.051)\end{array}$ & $\begin{array}{c}-0.0281 \\
(0.052)\end{array}$ & $\begin{array}{r}-0.0053 \\
(0.053)\end{array}$ \\
\hline Crime variable & $\begin{array}{c}0.0397 * * * \\
(0.008)\end{array}$ & $\begin{array}{c}0.0099 * * * * \\
(0.003)\end{array}$ & $\begin{array}{c}0.0607 * * * * \\
(0.015)\end{array}$ & $\begin{array}{c}0.0076^{* *} \\
(0.004)\end{array}$ \\
\hline Civil associations & $\begin{array}{c}0.0018^{* *} \\
(0.001)\end{array}$ & $\begin{array}{c}0.0024 * * * \\
(0.001)\end{array}$ & $\begin{array}{c}0.0027 * * * \\
(0.001)\end{array}$ & $\begin{array}{l}0.0013 \\
(0.001)\end{array}$ \\
\hline Unions & $\begin{array}{l}0.0014 \\
(0.002)\end{array}$ & $\begin{array}{l}0.0011 \\
(0.002)\end{array}$ & $\begin{array}{l}0.0012 \\
(0.002)\end{array}$ & $\begin{array}{l}0.0008 \\
(0.002)\end{array}$ \\
\hline Churches & $\begin{array}{c}-0.0007 * * * * \\
(0.000)\end{array}$ & $\begin{array}{c}-0.0008 * * * * \\
(0.000)\end{array}$ & $\begin{array}{c}-0.0009 * * * \\
(0.000)\end{array}$ & $\begin{array}{c}-0.0006 * * * \\
(0.000)\end{array}$ \\
\hline Opposition party & $\begin{array}{l}0.2837 \\
(0.218)\end{array}$ & $\begin{array}{l}0.3496 \\
(0.222)\end{array}$ & $\begin{array}{l}0.3423 \\
(0.224)\end{array}$ & $\begin{array}{l}0.1474 \\
(0.221)\end{array}$ \\
\hline Average schooling & $\begin{array}{c}0.5940 * * \\
(0.256)\end{array}$ & $\begin{array}{c}0.5563^{* *} \\
(0.252)\end{array}$ & $\begin{array}{c}0.6374 * * \\
(0.260)\end{array}$ & $\begin{array}{c}0.5553^{* *} \\
(0.245)\end{array}$ \\
\hline $\log (\mathrm{GDP})$ & $\begin{array}{l}0.1252 \\
(0.250)\end{array}$ & $\begin{array}{l}0.0933 \\
(0.257)\end{array}$ & $\begin{array}{l}0.0746 \\
(0.264)\end{array}$ & $\begin{array}{l}-0.0192 \\
(0.244)\end{array}$ \\
\hline Indigenous population & $\begin{array}{c}0.0295^{*} \\
(0.016)\end{array}$ & $\begin{array}{c}0.0314^{*} \\
(0.016)\end{array}$ & $\begin{array}{c}0.0366^{* *} \\
(0.017)\end{array}$ & $\begin{array}{c}0.0282 * \\
(0.015)\end{array}$ \\
\hline Lagged protest & $\begin{array}{l}0.0120 \\
(0.014)\end{array}$ & $\begin{array}{l}0.0216 \\
(0.016)\end{array}$ & $\begin{array}{c}0.0423^{* * *} * \\
(0.014)\end{array}$ & $\begin{array}{c}0.0410^{* * *} \\
(0.015)\end{array}$ \\
\hline Observations & 651 & 651 & 651 & 651 \\
\hline Number of states & 31 & 31 & 31 & 31 \\
\hline Log likelihood & -787.3 & -790.1 & -788.5 & -793.2 \\
\hline
\end{tabular}

Notes: Robust standard errors (OIM) in parentheses. ${ }^{* * *} \mathrm{p}<0.01, * * \mathrm{p}<0.05, * \mathrm{p}<0.1$. Additional variables come from different sources: Drug-related homicides (Presidencia de la República Mexicana, 2011), Disappearances (Registro Nacional de Datos de Personas Extraviadas o Desaparecidas), Number of cartels (Coscia and Rios, 2012). 
Table A4. Protest and Remittances: NB Additional controls; GINI, Libraries, Economic Activity

\begin{tabular}{|c|c|c|c|c|c|}
\hline VARIABLES & (1) & (2) & (3) & (4) & (5) \\
\hline Log(remittances) & $\begin{array}{c}4.2970^{* * * *} \\
(1.518)\end{array}$ & $\begin{array}{c}4.0287 * * * \\
(1.479)\end{array}$ & $\begin{array}{c}4.3447 * * * \\
(1.544)\end{array}$ & $\begin{array}{c}4.0767 * * * \\
(1.502)\end{array}$ & $\begin{array}{c}4.2219 * * * \\
(1.443)\end{array}$ \\
\hline $\log (\text { remittances })^{2}$ & $\begin{array}{c}-0.2880^{* * * *} \\
(0.108)\end{array}$ & $\begin{array}{c}-0.2674^{* *} \\
(0.106)\end{array}$ & $\begin{array}{c}-0.2849^{* * *} * \\
(0.110)\end{array}$ & $\begin{array}{c}-0.2660 * * \\
(0.107)\end{array}$ & $\begin{array}{c}-0.2870^{* * * *} \\
(0.103)\end{array}$ \\
\hline Emigration & $\begin{array}{r}-0.0147 \\
(0.051)\end{array}$ & $\begin{array}{r}-0.0132 \\
(0.051)\end{array}$ & $\begin{array}{r}-0.0165 \\
(0.051)\end{array}$ & $\begin{array}{r}-0.0152 \\
(0.051)\end{array}$ & $\begin{array}{l}0.0025 \\
(0.048)\end{array}$ \\
\hline Homicide rate & $\begin{array}{c}0.0397 * * * \\
(0.008)\end{array}$ & $\begin{array}{c}0.0393 * * * \\
(0.008)\end{array}$ & $\begin{array}{c}0.0413 * * * \\
(0.008)\end{array}$ & $\begin{array}{c}0.0407 * * * \\
(0.008)\end{array}$ & $\begin{array}{c}0.0408 * * * * \\
(0.008)\end{array}$ \\
\hline Civil associations & $\begin{array}{c}0.0018^{* *} \\
(0.001)\end{array}$ & $\begin{array}{c}0.0018^{* *} \\
(0.001)\end{array}$ & $\begin{array}{c}0.0020^{* *} \\
(0.001)\end{array}$ & $\begin{array}{c}0.0019 * * \\
(0.001)\end{array}$ & $\begin{array}{c}0.0018^{* *} \\
(0.001)\end{array}$ \\
\hline Unions & $\begin{array}{l}0.0014 \\
(0.002)\end{array}$ & $\begin{array}{l}0.0005 \\
(0.002)\end{array}$ & $\begin{array}{l}0.0017 \\
(0.002)\end{array}$ & $\begin{array}{l}0.0009 \\
(0.002)\end{array}$ & $\begin{array}{l}0.0013 \\
(0.002)\end{array}$ \\
\hline Churches & $\begin{array}{c}-0.0007^{* * * *} \\
(0.000)\end{array}$ & $\begin{array}{c}-0.0006^{* * * *} \\
(0.000)\end{array}$ & $\begin{array}{c}-0.0007 * * * \\
(0.000)\end{array}$ & $\begin{array}{c}-0.0007 * * * * \\
(0.000)\end{array}$ & $\begin{array}{c}-0.0006^{* * * *} \\
(0.000)\end{array}$ \\
\hline Opposition party & $\begin{array}{l}0.2837 \\
(0.218)\end{array}$ & $\begin{array}{l}0.2597 \\
(0.218)\end{array}$ & $\begin{array}{l}0.2237 \\
(0.224)\end{array}$ & $\begin{array}{l}0.2123 \\
(0.223)\end{array}$ & $\begin{array}{l}0.1790 \\
(0.213)\end{array}$ \\
\hline Average schooling & $\begin{array}{c}0.5940 * * \\
(0.256)\end{array}$ & $\begin{array}{c}0.6395 * * \\
(0.261)\end{array}$ & $\begin{array}{c}0.6302 * * \\
(0.256)\end{array}$ & $\begin{array}{c}0.6570 * * \\
(0.258)\end{array}$ & $\begin{array}{c}0.5121 * * \\
(0.244)\end{array}$ \\
\hline $\log (\mathrm{GDP})$ & $\begin{array}{l}0.1252 \\
(0.250)\end{array}$ & $\begin{array}{l}0.0871 \\
(0.253)\end{array}$ & $\begin{array}{l}0.1238 \\
(0.253)\end{array}$ & $\begin{array}{l}0.0894 \\
(0.254)\end{array}$ & \\
\hline Indigenous population & $\begin{array}{c}0.0295^{*} \\
(0.016)\end{array}$ & $\begin{array}{l}0.0259 \\
(0.016)\end{array}$ & $\begin{array}{c}0.0300^{*} \\
(0.016)\end{array}$ & $\begin{array}{l}0.0265 \\
(0.016)\end{array}$ & $\begin{array}{l}0.0218 \\
(0.014)\end{array}$ \\
\hline Lagged protest & $\begin{array}{l}0.0120 \\
(0.014)\end{array}$ & $\begin{array}{l}0.0096 \\
(0.015)\end{array}$ & $\begin{array}{l}0.0135 \\
(0.015)\end{array}$ & $\begin{array}{l}0.0113 \\
(0.015)\end{array}$ & $\begin{array}{l}0.0134 \\
(0.014)\end{array}$ \\
\hline GINI & & $\begin{array}{l}0.0618^{*} \\
(0.037)\end{array}$ & & $\begin{array}{l}0.0535 \\
(0.037)\end{array}$ & \\
\hline Libraries per capita & & & $\begin{array}{l}2.8212 \\
(1.949)\end{array}$ & $\begin{array}{l}2.3149 \\
(1.992)\end{array}$ & \\
\hline Economic Activity & & & & & $\begin{array}{c}0.0419 * * * \\
(0.013)\end{array}$ \\
\hline Observations & 651 & 651 & 651 & 651 & 651 \\
\hline Number of states & 31 & 31 & 31 & 31 & 31 \\
\hline Log likelihood & -787.3 & -785.9 & -786.2 & -785.2 & -782.2 \\
\hline
\end{tabular}


Table A5. Protest and Remittances: Cross-sectional evidence on Vigilantes and HTAs
(1)
(2)
(3)

VARIABLES

\begin{tabular}{|c|c|c|c|}
\hline Log(remittances $)$ & $\begin{array}{c}2.8746 * * \\
(1.275)\end{array}$ & $\begin{array}{c}2.6358 * * \\
(1.196)\end{array}$ & $\begin{array}{c}3.4979 * * * \\
(1.315)\end{array}$ \\
\hline $\log (\text { remittances })^{2}$ & $\begin{array}{c}-0.2511 * * * \\
(0.095)\end{array}$ & $\begin{array}{c}-0.2387 * * * \\
(0.089)\end{array}$ & $\begin{array}{c}-0.3115^{* * * *} \\
(0.100)\end{array}$ \\
\hline Emigration & $\begin{array}{c}0.2246 * * \\
(0.091)\end{array}$ & $\begin{array}{c}0.2680 * * * \\
(0.092)\end{array}$ & $\begin{array}{c}0.2668 * * * \\
(0.088)\end{array}$ \\
\hline Homicide rate & $\begin{array}{c}0.1377 * * * \\
(0.020)\end{array}$ & $\begin{array}{c}0.1300 * * * \\
(0.020)\end{array}$ & $\begin{array}{c}0.1294 * * * \\
(0.019)\end{array}$ \\
\hline Civil associations & $\begin{array}{c}-0.0026 * * \\
(0.001)\end{array}$ & $\begin{array}{c}-0.0023^{*} \\
(0.001)\end{array}$ & $\begin{array}{c}-0.0021 * \\
(0.001)\end{array}$ \\
\hline Unions & $\begin{array}{c}0.0040 * * \\
(0.002)\end{array}$ & $\begin{array}{c}0.0034 * * \\
(0.002)\end{array}$ & $\begin{array}{c}0.0040 * * \\
(0.002)\end{array}$ \\
\hline Churches & $\begin{array}{l}0.0002 \\
(0.000)\end{array}$ & $\begin{array}{l}0.0001 \\
(0.000)\end{array}$ & $\begin{array}{l}0.0001 \\
(0.000)\end{array}$ \\
\hline Opposition party & $\begin{array}{c}-0.1823 \\
(0.229)\end{array}$ & $\begin{array}{c}-0.2699 \\
(0.220)\end{array}$ & $\begin{array}{r}-0.1847 \\
(0.218)\end{array}$ \\
\hline Average schooling & $\begin{array}{l}0.3089 \\
(0.218)\end{array}$ & $\begin{array}{l}0.2946 \\
(0.212)\end{array}$ & $\begin{array}{c}0.3455^{*} \\
(0.206)\end{array}$ \\
\hline $\log (\mathrm{GDP})$ & $\begin{array}{l}0.0285 \\
(0.231)\end{array}$ & $\begin{array}{l}0.1470 \\
(0.222)\end{array}$ & $\begin{array}{c}0.0791 \\
(0.222)\end{array}$ \\
\hline Indigenous population & $\begin{array}{l}0.0110 \\
(0.013)\end{array}$ & $\begin{array}{l}0.0131 \\
(0.013)\end{array}$ & $\begin{array}{l}0.0146 \\
(0.013)\end{array}$ \\
\hline Hometown migrant associations & $\begin{array}{l}0.0016 \\
(0.001)\end{array}$ & & $\begin{array}{l}0.0023 \\
(0.001)\end{array}$ \\
\hline Vigilante group & & $\begin{array}{l}0.2879 \\
(0.217)\end{array}$ & $\begin{array}{c}0.4035 * \\
(0.221)\end{array}$ \\
\hline $\begin{array}{l}\text { Observations } \\
\text { Log likelihood }\end{array}$ & $\begin{array}{c}31 \\
-103.6\end{array}$ & $\begin{array}{c}31 \\
-103.4\end{array}$ & $\begin{array}{c}31 \\
-102.1\end{array}$ \\
\hline
\end{tabular}

Notes: Robust standard errors in parentheses. $* * * \mathrm{p}<0.01, * * \mathrm{p}<0.05, * \mathrm{p}<0.1$. Additional variables come from different sources: Hometown migrant associations (Instituto de los Mexicanos en el Exterior, 2015) and vigilante groups (Phillips, 2017) 
Table A6. Protest and Remittances: Alternative Instrumental Variables

\begin{tabular}{|c|c|c|c|}
\hline Dep. Var. Protests & $\begin{array}{c}\text { First stage } \\
\text { Remittances } \\
\text { (1) }\end{array}$ & $\begin{array}{c}\text { First stage } \\
\text { Remittances }{ }^{2} \\
(2)\end{array}$ & $\begin{array}{l}\text { Second stage } \\
\text { Protest } \\
\text { (3) }\end{array}$ \\
\hline Log(remittances) & & & $\begin{array}{c}15.0200 * * \\
(7.291)\end{array}$ \\
\hline $\log (\text { remittances })^{2}$ & & & $\begin{array}{c}-0.9011 * * \\
(0.429)\end{array}$ \\
\hline Emigration & $\begin{array}{c}0.0989 * * * \\
(0.007)\end{array}$ & $\begin{array}{c}1.4476 * * * \\
(0.099)\end{array}$ & $\begin{array}{c}-0.1944 \\
(0.162)\end{array}$ \\
\hline Homicide rate & $\begin{array}{l}0.0007 \\
(0.001)\end{array}$ & $\begin{array}{r}-0.0027 \\
(0.012)\end{array}$ & $\begin{array}{c}0.0415 * * * \\
(0.014)\end{array}$ \\
\hline Civil associations & $\begin{array}{c}0.0008 * * * \\
(0.000)\end{array}$ & $\begin{array}{c}0.0109 * * * \\
(0.002)\end{array}$ & $\begin{array}{c}-0.0001 \\
(0.001)\end{array}$ \\
\hline Unions & $\begin{array}{c}0.0008^{* * * *} \\
(0.000)\end{array}$ & $\begin{array}{c}0.0118 * * * \\
(0.003)\end{array}$ & $\begin{array}{r}-0.0021 \\
(0.003)\end{array}$ \\
\hline Churches & $\begin{array}{c}-0.0002 * * * \\
(0.000)\end{array}$ & $\begin{array}{c}-0.0026 * * * \\
(0.000)\end{array}$ & $\begin{array}{l}0.0004 \\
(0.000)\end{array}$ \\
\hline Opposition party & $\begin{array}{c}-0.0988 * * * \\
(0.033)\end{array}$ & $\begin{array}{c}-0.9868 * * \\
(0.464)\end{array}$ & $\begin{array}{l}0.5566 \\
(0.380)\end{array}$ \\
\hline Average schooling & $\begin{array}{c}-0.2701 * * * \\
(0.021)\end{array}$ & $\begin{array}{c}-3.4576 * * * \\
(0.302)\end{array}$ & $\begin{array}{l}0.9092 \\
(0.574)\end{array}$ \\
\hline Indigenous population & $\begin{array}{c}-0.0091 * * * \\
(0.002)\end{array}$ & $\begin{array}{c}-0.0890 * * * \\
(0.024)\end{array}$ & $\begin{array}{c}0.0610 * \\
(0.034)\end{array}$ \\
\hline Log (population) & $\begin{array}{c}1.3448 * * * \\
(0.051)\end{array}$ & $\begin{array}{c}17.8102^{* * *} * \\
(0.670)\end{array}$ & $\begin{array}{l}-4.3802 \\
(2.832)\end{array}$ \\
\hline $\log (\mathrm{GDP})$ & $\begin{array}{c}-38.4995 * * * \\
(12.933)\end{array}$ & $\begin{array}{c}-527.2928 * * * \\
(172.166)\end{array}$ & $\begin{array}{c}2.1861^{*} \\
(1.246)\end{array}$ \\
\hline Lagged protest & $\begin{array}{c}-0.0139 * * * \\
(0.005)\end{array}$ & $\begin{array}{c}-0.1904 * * \\
(0.074)\end{array}$ & $\begin{array}{c}0.3528 * * * \\
(0.105)\end{array}$ \\
\hline IV Unemployment & $\begin{array}{c}-0.0178 * * * \\
(0.007)\end{array}$ & $\begin{array}{c}-0.1777 * * \\
(0.088)\end{array}$ & \\
\hline$I V \log (G D P)^{2}$ & $\begin{array}{c}2.9787 * * * \\
(1.041)\end{array}$ & $\begin{array}{c}40.4865 * * * \\
(13.883)\end{array}$ & \\
\hline$I V \log (G D P)^{3}$ & $\begin{array}{c}-0.0775^{* * *} \\
(0.028)\end{array}$ & $\begin{array}{c}-1.0421 * * * \\
(0.372)\end{array}$ & \\
\hline R-squared & 0.918 & 0.914 & 0.080 \\
\hline $\mathrm{F}$ & 10.11 & 14.43 & - \\
\hline Sanderson-Windmeijer F & 9.37 & 12.22 & - \\
\hline Sanderson-Windmeijer Chi2 & 19.18 & 25.02 & - \\
\hline Kleibergen-Paap rk LM & - & - & 12.482 \\
\hline Kleibergen-Paap rk Wald F & - & - & 4.367 \\
\hline Observations & 651 & 651 & 651 \\
\hline
\end{tabular}

Robust standard errors in parentheses; *** $\mathrm{p}<0.01,{ }^{* *} \mathrm{p}<0.05,{ }^{*} \mathrm{p}<0.1$. In this specification we use the exogenous unemployment IV, plus the quadratic and cubic terms of GDP per capita. These two additional instruments are in fact correlated with remittances, and they can arguably be excluded from the main equation. The end result is a system of equations with three excluded instruments. The intuition is that nonlinear functions of the endogenous variable have a linear projection that depends on new functions of the exogenous variables. 